Please do not remove this page

RMIT

UNIVERSITY

\title{
The monitored performance of the first new London dwelling certified to the Passive House standard
}

Ridley, Ian; Clarke, Alan; Bere, Justin; Altamirano-Medina, H; Lewis, Sarah; Durdev, Mila; Farr, Andrew https://researchrepository.rmit.edu.au/esploro/outputs/9921862205901341/filesAndLinks?institution=61RMIT_INST\&index=null

Ridley, I., Clarke, A., Bere, J., Altamirano-Medina, H., Lewis, S., Durdev, M., \& Farr, A. (2013). The monitored performance of the first new London dwelling certified to the Passive House standard. Energy and Buildings, 63, 67-78. https://doi.org/10.1016/j.enbuild.2013.03.052

Document Version: Submitted Version

Published Version: https://doi.org/10.1016/j.enbuild.2013.03.052

Repository homepage: https://researchrepository.rmit.edu.au (C) 2013 Elsevier

Downloaded On 2023/04/26 23:29:28 +1000 
Thank you for downloading this document from the RMIT Research Repository.

The RMIT Research Repository is an open access database showcasing the research outputs of RMIT University researchers.

RMIT Research Repository: http://researchbank.rmit.edu.au/

\section{Citation:}

Ridley, I, Clarke, A, Bere, J, Altamirano-Medina, H, Lewis, S, Durdev, M and Farr, A 2013, 'The monitored performance of the first new London dwelling certified to the Passive House standard', Energy and Buildings, vol. 63, pp. 67-78.

See this record in the RMIT Research Repository at:

http://researchbank.rmit.edu.au/view/rmit:20974

Version: Submitted Version

Copyright Statement: ㄷ 2013 Elsevier

Link to Published Version:

http://dx.doi.org/10.1016/j.enbuild.2013.03.052 
Ian Ridley ${ }^{1}$, Alan Clarke ${ }^{2}$, Justin Bere ${ }^{3}$, Hector Altamirano $^{4}$, Sarah Lewis $^{3}$, Mila Durdev $^{3}$, Andrew Farr $^{5}$

${ }^{1}$ School of Property, Construction and Project Management, RMIT University, GPO Box 2476, Melbourne, VIC 3001, Australia.

${ }^{2}$ Alan Clarke Consultants, The Woodland, Whitecroft, Lydney, GL15 4PL, UK.

${ }^{3}$ Bere Architects, London, Mildmay Centre, Woodville Road, London N16 8NA, UK.

${ }^{4}$ The Bartlett School of Graduate Studies, UCL, Central House, 14 Upper Woburn Place,

WC1H ONN London, UK.

${ }^{5}$ The Green Building Store, Heath House Mill, Heath House Lane, Golcar, Huddersfield HD7 4JW

Corresponding author ian.ridley@rmit.edu,au.

Tel +61 399258246

Fax +61 399251939 


\section{$\underline{\text { Abstract }}$}

The monitored performance of the first new London dwelling certified to the Passive House standard is presented. The first detailed analysis of the energy consumption of the heating, ventilation and domestic hot water systems are given. The annual space heating demand of the 2 bedroom, $101 \mathrm{~m}^{2}$ dwelling was 12.1 $\mathrm{kWh} / \mathrm{m}^{2}$, achieving the $15 \mathrm{kWh} / \mathrm{m}^{2}$ Passive House target. The annual primary energy demand was $125 \mathrm{kWh} / \mathrm{m}^{2}$, marginally above the $120 \mathrm{kWh} / \mathrm{m}^{2}$ target. The measured internal heat gains of $3.65 \mathrm{~W} / \mathrm{m}^{2}$ are much greater than the $2.1 \mathrm{~W} / \mathrm{m}^{2}$ suggested as standard for dwellings. The Passive House Planning Package, PHPP, is found to be a good predictor of space heating demand and the risk of summer time over heating. Winter space heating demand is sensitive to occupant blind use. With a total metered energy consumption of $65 \mathrm{kWh} / \mathrm{m}^{2}$, the Camden Passive house is one of the lowest energy, small family dwellings, monitored in the UK.

Keywords: Dwellings, Low Energy, Building performance, Passive House, Space Heating, Ventilation 1.1 Introduction and Background

This paper reports on the thermal and energy performance of the Camden Passive House, built in London in 2010. Designed by Bere Architects, the house is being monitored under the Technology Strategy Board, Building Performance Evaluation Programme. The project received support for post construction evaluation and ongoing monitoring of performance for 2 years, which is supervised by supervised by a team of independent academics.

The Passive House standard is a rigorous, voluntary building standard conceived in Germany in 1988 as a result of collaboration between Professors Bo Adamson of Lund University, Sweden, and Wolfgang Feist, founder of the Passivhaus Institute. It is based on the principle of primarily minimizing the heat loss through highly insulated, airtight and thermal bridging free construction. Heating demand is further minimized by means of passive solar heating and reduction of ventilation heat losses through use of mechanical ventilation with heat recovery (MVHR). As a result, heating demand is so low that the conventional heating system can be omitted, with heat provided by pre-heating the air supplied by the ventilation system. In order to achieve Passive House certification, a building needs to meet three basic criteria [1]:

- Specific Space Heat Demand max $15 \mathrm{kWh} / \mathrm{m}^{2}$

- Entire Specific Primary Energy Demand $\max 120 \mathrm{kWh} / \mathrm{m}^{2}$

- Pressurization Test Result max $0.6 \mathrm{~h}^{-1} @ 50 \mathrm{~Pa}$

The building performance is assessed using Passivhaus Planning Package (PHPP). It has been estimated that in 2012 there are approximately 64,000 Passive House standard dwellings in Europe [2]. The monitored 
performance of over 100 dwellings from 11 EU CEPHEUS (Cost Efficient Passive Houses as European Standards) projects found that Passive Houses achieved a space heating demand of 15 to $20 \%$ of conventional new buildings [3]. In the UK a small number of passive houses both new builds and retrofits have been built, and are currently being evaluated and monitored. The Princedale Road Passive House retrofit project, which is being monitored under the Retrofit for the future programme, has reported an annual energy (electricity) consumption of $5436 \mathrm{kWh}$ in an $87 \mathrm{~m}^{2}$ dwelling, hence a primary energy demand of 169 $\mathrm{kWh} / \mathrm{m}^{2}$, between March 2011 and April 2012, thus exceeding the Passive House primary energy demand target by $41 \%$ [4]. The Lime and Larch Passive houses, [5], designed by the same team behind the Camden Passive House are also being monitored under the Technology Strategy Board, Building Performance Evaluation scheme, results of the first year of monitored occupation will be available in May 2013. The construction of the first Passive Houses in the UK can be put in the context of current UK Building Regulations [6], The Code for Sustainable Home, [7] and strategies to achieve "Zero Carbon" housing from 2016 [8]. Current UK good practice is defined within the Fabric Energy Efficiency Standard (FEES) which aims to limit heating and cooling demand to reasonable levels so that LZC technologies can be used in an efficient way and thus guarantee achievement of carbon compliance and consequently "Zero Carbon" operation. According to FEES [9], maximum space heating and cooling energy demand should be:

- $39 \mathrm{kWh} / \mathrm{m}^{2} / \mathrm{yr}$ for apartments and mid terrace houses

- $46 \mathrm{kWh} / \mathrm{m}^{2} / \mathrm{yr}$ for end of terrace, semi detached and detached houses

Building performance evaluation has shown that the gap between predicted or "designed" and actual performance of low energy dwellings can be significant and that it partially originates from failures in detailing, construction of the building fabric and installation and commissioning of services $[10,11,12]$. Similarly it has been shown that occupant behaviour is also an important factor in the performance of low energy dwellings [13,14]. In a group of recently monitored low energy UK dwellings, [15], it was found that space heating and domestic hot water varied by a factor of 3 between similar households, and water use by a factor 7. Great care must be taken not to over state the results from single case study houses, only when the monitored performances of several UK Passive House dwellings become available, will an assessment of their overall performance be possible.

\section{$\underline{1.2 \text { Aims and Objectives }}$}

The Camden Passive House is an interesting case study in that it provides hard evidence of the performance of a Passive House standard dwelling built in the UK, allowing comparison with design targets and predictions of design tools. As the number of Passive House dwellings in the UK is very limited, there is 
little or no data on the performance of these types of houses, not only in terms of space heating and domestic hot water demand but in terms of the temperature, internal gains, moisture and ventilation performance. The aims of this paper are therefore two fold, firstly to present evidence on the performance of this case study dwelling and secondly to provide metrics and insight on the performance of low energy dwellings in the UK in a more generic form suitable for those interested in assessing and understanding the impacts of low energy design and refurbishment on energy, temperature and occupant health. Simulation studies, $[16,17]$, have identified the potential health benefits of MVHR systems, by reducing the risk of mould, concentrations of indoor generated pollutants such as PM2.5 from cooking, the build up of radon, and the reduction in ingress of externally generated PM2.5. The findings of these studies however have to be placed in the context that there is little monitored data, with the exception of the Derwentside study, [18] on the as built performance, quality of commissioning, reliability, fan power and efficiency of MVHR systems in the UK. The PHPP tool played an integral role in designing the house [19] this paper compares the real and predicted performance. The house successfully achieved passive house certification and post completion pressure testing determined that the target level of air tightness had been achieved. This paper presents the results of the first year of monitoring; the primary aims of the paper are to analyse:

1. Winter space heating consumption

2. Comparison of PHPP predictions with measured data

3. Summer time over heating risk

4. Commissioning, specific fan power and efficiency of MVHR system

\subsection{The Camden Passive House}

This timber framed $101 \mathrm{~m}^{2}$, two bedroom house is the first certified new build Passive House in London. The primary objective of the project was to achieve a comfortable home for the client's young family, while minimizing energy consumption. The $101 \mathrm{~m}^{2}$, two bedroom, family house is constructed with a heavily insulated prefabricated timber frame set inside $3 \mathrm{~m}$ retaining walls and clad in European larch. The $U$ values of the upper external walls and sloping roof are both $0.11 \mathrm{~W} / \mathrm{m}^{2} \mathrm{~K}$, the ground floor slab has a $\mathrm{U}$ value of 0.1 $\mathrm{W} / \mathrm{m}^{2} \mathrm{~K}$, while the flat roof has a $\mathrm{U}$ value of $0.067 \mathrm{~W} / \mathrm{m}^{2} \mathrm{~K}$. The site is located in London which means that the over-shadowing of adjacent buildings had a major impact on the energy balance and design decisions. The Passivhaus Planning Package (PHPP) was used from the very start of the project to determine the optimum position for the house on the site and the optimum percentage and orientation of the glazing. The final design of the house provides bright and airy rooms with large, tilt and slide, draught-free triple-glazed windows to the south and west. Summer shading is provided by means of retractable external venetian blinds with automatic solar control, whilst inward-tilting windows provide secure summer night-time purge 
ventilation. Careful detailing and use of air tight vapour control layers resulted in a very air tight construction, with post completion pressurisation testing measuring an air infiltration rate of $0.44 \mathrm{ach}^{-1}$ at $50 \mathrm{~Pa}$, below the PHPP target of $0.6 \mathrm{ach}^{-1}$ at 50Pa. The house is ventilated by a Paul Thermos $200 \mathrm{MVHR}$ unit located in an insulated enclosure in the bike shed attached to the building, with a quoted heat recovery efficiency of $92 \%$. The system is designed to provide a constant background ventilation rate of $130 \mathrm{~m}^{3} / \mathrm{hr}(36 \mathrm{l} / \mathrm{s}), 0.48 \mathrm{ach}$. Space heating is provided by a $1 \mathrm{~kW}$ heater battery in the supply air duct of the ventilation system, supplying warm air at $55^{\circ} \mathrm{C}$, complemented by heated towel rails on demand in the bathrooms. A Viessman Vitodens 343F compact energy tower system, comprising of a condensing gas boiler, integrated 200 litre hot water cylinder with direct solar thermal connection supplies heat to the heating system and for domestic hot water. A south facing $3 \mathrm{~m}^{2}$ Vitosol 200 , evacuated tube solar collector is installed on the flat roof.

Figure 1 Photograph of south façade of completed house. (Source Tim Crocker) A water filtration system ensures clean water for both drinking and bathing. Mains water use is reduced by an underground rainwater-harvesting tank, which provides water for the garden. $\mathrm{PHPP}$ predicted annual $\mathrm{CO}_{2}$ emissions are $11.3 \mathrm{~kg}$ excluding appliances and $23.6 \mathrm{~kg}$ overall. Biodiversity was very important for this project which incorporates two, wild flower meadow green roofs, a south facing garden and, an ivy covered gabion stone wall. The house is occupied by two professional, young adults, who do not work from home.

\subsection{Monitoring System}

An Eltek wireless data logging and monitoring system, compliant with the specification of the BPE programme and the UK Energy Saving Trust CE 298 [20] protocol, was installed in July 2011. All data is recorded at 5 minute intervals. The details of the system are as follows.

- An on site Weather Station measures Dry Bulb Temperature, Relative Humidity, Wind Speed and Direction, Global Solar Radiation, Atmospheric Pressure, Precipitation.

- $\quad$ Room Temperature and Relative Humidity are measured in the Living Room, Kitchen, Master Bedroom, En-suite Bathroom, and Guest Bedroom. Concentrations of $\mathrm{CO}_{2}$ are monitored in the Living Room and Master Bedroom.

- Utilities metering consists of Total Electricity, Total Gas, Total Water Consumption, with further detailed electricity sub metering on the following circuits: Kitchen Sockets, Down Sockets, Up Lights, Up Sockets, Down Lights, Blinds, Hob, Utility Room Sockets, Oven, Auxiliary Loads, Mechanical Ventilation and Heat Recovery (MVHR). 
- Duct Temperatures are measured at the following positions in the MVHR system: Air Off heater, Duct Heater Flow, Duct Heater Return, MVHR Supply, MVHR Extract, MVHR Intake, Master bedroom Supply, Living Room Supply, and Kitchen Extract.

- Heat Meters were installed on the hydronic systems to measure the space heating supplied by the Heater Battery in the MVHR supply, the space heat supplied by the towel rails in the bathrooms, the solar input to the hot water cylinder, Domestic Hot Water Consumption.

The monitoring system was designed to measure the space heat output from both towel rails using one heat meter, however during installation access could only be gained to insert the heat meter at a location after the two circuits had split from the joint feed. Hence it was only possible to measure the heat input from the towel rail in the master bedroom, not on the second en suite in the guest bedroom. However the heating system is configured in such a way that if the heater battery in the MVHR duct switches on, the towel rails both switch on at the same time. Therefore it is known that the output from the guest en suite towel rail will be equal to measured output of the en suite towel rail, if the MVHR heater is on. The Master en suite towel rail was monitored to switch on at times the MVHR heater battery was not on, contributing an extra $150 \mathrm{kWh}$ in winter. A site visit in autumn 2011 found that the second towel rail was not working correctly and not providing heat. The results presented assume that the second towel rail was not used to provide supplemental heat, when the MVHR heater battery was off. During the first year of monitoring approximately 3 weeks of data was lost, due to equipment failure or unplanned events at the dwelling. It was assumed that consumption during these missing days was equal to the daily average of the month during which the loss occurred.

\subsection{Results}

The monitoring system was installed in July 2011, in this paper we present the data from the first full year of monitoring, from August 2011 to July 2012 inclusive. We will concentrate on the heating season performance between October 2011 and Mar 2012 inclusive. A summary of the month by month performance of the house, in terms of energy consumption, internal and external temperature is given in Tables 1 to 6 , and Figures 2 and 3. The average electricity power consumption during the first year was 3.87 $\mathrm{W} / \mathrm{m}^{2}$. With occupancy of 2 people, the per capita electricity consumption was $1680 \mathrm{kWh} /$ person. The Electricity consumption can be compared to the UK average and that of the recent EST household electricity use study [21]. The typical average annual domestic electricity consumption currently used in the UK is 3,300 kWh [22]. The EST study households were using on average 3,638 kWh which is ten per cent higher 
than the official average consumption figures. Average per capita consumption for the EST study was 2,012, kWh/person compared with1,375 kWh/person nationally.

Table 1 Electricity Consumption (kWh)

Table 2 Gas consumption, Space Heating and Domestic Hot Water consumption (kWh)

Table 3 Average Room Temperatures ${ }^{\circ} \mathrm{C}$ and Relative Humidity $\%$ and Weather Conditions

Table 4 Summer time Over-heating, \% of Hours over $25^{\circ} \mathrm{C}$ and $28{ }^{\circ} \mathrm{C}$

During the first six months of monitoring a number of faults were identified and subsequent adjustments were made to the boiler and solar thermal system (see Section 4.1 Forensic investigation, troubleshooting and interventions). At the end of the year the parasitic loads had been reduced to $16 \%$ of the electricity consumption. The total auxiliary or parasitic energy consumption of the boiler, pumps and MVHR system was measured to be $1222 \mathrm{kWh}$. After adjustments and trouble shooting, results from the final 5 months of monitoring suggest that this value had been reduced to $708 \mathrm{kWh}$. The PHPP predicted auxiliary electricity demand was $645 \mathrm{kWh}$.

Total Space heating consumption Winter 2011/12 between October and March inclusive is $1220 \mathrm{kWh}$, $12.1 \mathrm{kWh} / \mathrm{m}^{2}$. The total annual gas consumption of the house was $3217 \mathrm{kWh}$. This can be compared to the average gas consumption of a dwelling in greater London, between 2005-2010, of 16,500kWh [23]. It can be seen that distribution, storage and boiler losses account for $27 \%$ of the gas consumption. Assuming an annual average boiler efficiency of $90 \%$ the distribution and storage losses (DSL) of the heating and DHW system can be estimated using Equation 1.

DSL $(k W h)=(0.9 *$ Gas Consumption $)+$ Solar Input - Space Heat Consumption - DHW Consumption Eqtn 1.

The annual space heating and DHW distribution and storage losses for the house were $1085 \mathrm{kWh}$, or $10.7 \mathrm{kWh} / \mathrm{m}^{2}$. This figure is in line with the $10 \mathrm{kWh} / \mathrm{m}^{2}$ figure of DHW heat losses recorded in other UK low energy dwellings [24]. From August to February it is known that there was a problem with the solar hot water controller. The solar pump was on 24 hours a day; hence at night the cylinder was effectively losing heat to the solar panel. After February, when this issue was resolved the losses are reduced by $28 \%$ and the average rate of loss was $74 \mathrm{kWh}$ per month, or a heat loss rate $1.0 \mathrm{~W} / \mathrm{m}^{2}$. It should be noted that prior to the middle of January, the heat from the MVHR heater battery was not being efficiently transferred to the supply air due to a partially closed valve, the heat consumption of the MVHR heater battery during this time was 290 kWh. 
The total gas and electricity consumption of the house in the first year of monitoring was $6576 \mathrm{kWh}$, or 65.1 $\mathrm{kWh} / \mathrm{m}^{2}$ per annum. The Camden Passive House is therefore one of the lowest energy dwellings ever monitored in the UK. The BedZed development consumed approximately $90 \mathrm{kWh} / \mathrm{m}^{2}$, The Long House 80 $\mathrm{kWh} / \mathrm{m}^{2}$ [15], The Bioregional One Brighton apartments have a median energy consumption of $72 \mathrm{kWh} / \mathrm{m}^{2}$ [25]. Only the Princedale Road retrofit dwelling with a total energy consumption of $62.5 \mathrm{kWh} / \mathrm{m}^{2}$ is less than the Camden passive House.

Assuming the PHPP primary energy factors of 1.1 for gas and 2.7 for electricity; the primary energy demand of the dwelling was $12600 \mathrm{kWh}$ or $125 \mathrm{kWh} / \mathrm{m}^{2} ; 4 \%$ greater than $120 \mathrm{kWh} / \mathrm{m}^{2}$ target. Assuming a UK carbon intensity of $0.19 \mathrm{~kg} \mathrm{CO}_{2}$ per $\mathrm{kWh}$ from gas and $0.422 \mathrm{~kg} \mathrm{CO}_{2}$ from delivered electricity, the house emitted $2030 \mathrm{~kg} \mathrm{CO}$, or $20.5 \mathrm{~kg} / \mathrm{m}^{2}$ per annum. Removing appliance socket loads, the house emitted $1440 \mathrm{~kg} \mathrm{CO}$ for lighting, space heating, domestic hot water and auxiliary loads, $14.5 \mathrm{~kg} \mathrm{CO}_{2} / \mathrm{m}^{2}$ per annum.

Average winter living room temperatures, $22.4{ }^{\circ} \mathrm{C}$ are slightly higher than expected. Figure 2 gives a frequency distribution of the number of hours the heating system operated as a function of living room temperature. The heating system is observed to be sometimes on even during periods of high indoor temperature. The thermostat would appear to be set at a high value. The heating operates for 200 hours when the living room temperature is already above $24^{\circ} \mathrm{C}$.

Figure 2 Distribution of hours the heating system operated as a function of living room temperature.

\subsection{Dwelling Heat Loss and Summer Window Ventilation}

The total heat loss of the dwelling, ( fabric and infiltration) was measured in December 2012 by a Co-heating test following the methodology of Wingfield et al [26 ]. Full details of test are given by Stamp [27 ].The total heat loss ( with the MVHR unit switched off) was measured to be $56 \mathrm{~W} / \mathrm{K} \pm 5 \mathrm{~W} / \mathrm{K}$. This compares favourably to the design figure of $66 \mathrm{~W} / \mathrm{K}$, suggesting that the dwelling envelope had been constructed without significant defects.

The summer dwelling heat loss was calculated as follows. The daily rate of heat input to the dwelling in summer was regressed against the daily internal - external temperature difference. The total heat input consisted of all gains from electricity consumption, (except the MVHR unit which is situated outside the heated envelope), occupancy gains, solar gains and space heating, gains from distribution and storage 
losses of the domestic hot water system, but allowing for cold water feed and evaporation losses. Solar gains are calculated using Equation 2. [28]

$\mathrm{G}_{\text {solar }}=0.9 \times \mathrm{A}_{\mathrm{w}} \times \mathrm{S} \times \mathrm{g} \times \mathrm{FF} \times \mathrm{Z}$

Eqtn. 2

Where

0.9 is a factor representing the ratio of typical average transmittance to that at normal incidence

$A_{w}$ is the area of an opening (a window or a glazed door), $\mathrm{m}^{2}$

$\mathrm{S}$ is the solar flux on a surface, $\mathrm{W} / \mathrm{m}^{2}$

$\mathrm{g}$ is the total solar energy transmittance factor of the glazing at normal incidence

FF is the frame factor for windows and doors (fraction of opening that is glazed)

$\mathrm{Z}$ is the solar access factor

The values of $g, F F, Z$ are set equal to those used in PHPP, $S$ the solar flux on each façade is calculated from the horizontal global solar irradiance measured on site. The summer heat loss can be expected to increase with external temperature as windows are opened, thus increasing the ventilation heat loss. In Figure 3 the daily average heat loss is plotted against the daily average external temperature. As external temperatures decreases the summer heat loss tends to the value measured in the co heating test, that is the constant fabric and MVHR ventilation heat loss. A good correlation between heat loss and external temperature is seen. If it is assumed that the increased heat loss is solely due to increased window opening, (some increased blind use may also occur reducing heat gain, leading to an effective increase in dwelling heat loss), the daily window ventilation rate can be estimated. The constant fabric and MVHR ventilation heat loss is subtracted from the total daily heat loss; the ventilation rate is then calculated using the dwelling volume and daily average internal minus external temperature difference. The daily average window ventilation rate is plotted as a function of external temperature in Figure 4. Again it can be seen that there is a good correlation between external temperature and window ventilation rate. The average summer window ventilation rate is $0.14 \mathrm{ach}^{-1}$, increasing to over $1 \mathrm{ach}^{-1}$ on the hottest summer days. Window opening in the UK and in the Netherlands has previously found to be a function of external temperature [29, 30]. The data from the Camden passive House suggest that occupants in UK passive houses also increase window opening in summer in response to external temperature.

Figure 3 Summer Heat Loss and Window Opening 


\subsection{Summertime Overheating}

CIBSE (Chartered Institute of Building Services Engineers) standard, [31] requires that: For living areas, less than 1 per cent of occupied hours are over an operative temperature of $28^{\circ} \mathrm{C}$. For bedrooms, less than 1 per cent of occupied hours are over $26^{\circ} \mathrm{C}$. In the Camden Passive House the living air temperature exceeds $28^{\circ} \mathrm{C}$ for 123 hours, and the master bedroom air temperature exceeds $26^{\circ} \mathrm{C}$ for 43 hours. It should be noted that the monitoring system measures air temperature rather than operative temperature, $T_{o p}$. In summer one would expect the operative temperature to be slightly higher than the air temperature due to the slightly higher mean radiant temperature of some surfaces. A calibrated Energy Plus model of the Camden passive house predicts that the living room operative temperature is on average $0.4^{\circ} \mathrm{C}$, higher than the living room air temperature in summer, and occasionally $1.0^{\circ} \mathrm{C}$ higher. The PHPP planning package recommends that temperatures should not exceed $25{ }^{\circ} \mathrm{C}$ for more than $10 \%$ of the year. In the Camden house $25{ }^{\circ} \mathrm{C}$ is exceeded in the living room for $15 \%$ of the year. In summer time the living room exceeds $25{ }^{\circ} \mathrm{C}$, for $22.5 \%$ of hours. The master bedroom exceeds $25^{\circ} \mathrm{C}$ for less than $3 \%$ of the year, and the average dwelling temperature exceeds $25{ }^{\circ} \mathrm{C}$ for $6 \%$ of the year. Substituting measured external temperature, global horizontal solar radiation and internal heat gains into PHPP, the number of hours of overheating above $25{ }^{\circ} \mathrm{C}$ is predicted to be $17 \%$. In Figure 4 the measured distribution of living room temperatures is compared with that predicted by PHPP. PHPP is found to be a very good predictor of overheating risk.

Figure 4 Comparison of measured and PHPP predicted overheating frequency

BS EN 15251 (2007), [32] defines the comfort temperature in a free running building (the case of the Camden house in summer), according to the running mean of the outdoor temperature, $T_{r m}$, using the formula $T_{\text {comf }}=0.33 T_{r m}+18.8$. For Class II (normal level of expectation), suitable for new buildings and renovations, the allowable maximum difference between this comfort temperature and the actual indoor operative temperature is $\pm 3^{\circ} \mathrm{C}$. In the Camden Passive House in summer $94 \%$ of the hourly living room air temperature readings lie in the EN 15251 Class II comfort band. If the operative temperature is assumed to be $0.4^{\circ} \mathrm{C}$ higher than the air temperature, this is reduced to $92 \%,(90 \%$ if only occupied hours are considered).

Three additional criteria to measure the severity of overheating exceedence are also suggested in EN 15251. The building is judged to have an unacceptable level of overheating if any two of the three criteria are exceeded. 
Criteria 1 - Hours of Exceedence $\left(\mathrm{H}_{\mathrm{e}}\right)$ : The number of hours the measured operative temperature, $\mathrm{T}_{\mathrm{op}}$ exceeds the upper limit of the band of acceptable comfort temperatures by $1^{\circ} \mathrm{C}$, or more, should not exceed $3 \%$ of the total occupied hours or 40 hours, during summer months. For a Class II building, $\mathrm{T}_{\max }=\mathrm{T}_{\text {comf }}+4$. In the Camden Passive House the hours of exceedence $\mathrm{H}_{e}$, based on operative temperature are $5 \%$ during occupied hours.

Criteria 2 - Weighted Exceedence $\left(W_{e}\right)$ : For each day the sum of the weighted exceedence for each degree ${ }^{\circ} \mathrm{C}$ above $\mathrm{T}_{\max }$ the allowable maximum should be less than 10.0; where $\mathrm{We}=\Sigma \mathrm{H}_{\mathrm{e}}{ }^{*}(\Delta \mathrm{T})^{2}$ and $\Delta \mathrm{T}=\left(\mathrm{T}_{\mathrm{op}}-\right.$ $T_{\max }$ ), rounded to a whole number. In the Camden Passive House three days in summer fail the weighted exceedence.

Criteria 3 - Threshold/Upper Limit Temperature ( $\left.T_{\text {upp }}\right)$ : The measured operative temperature should not exceed the $\mathrm{T}_{\max }$ by $3^{\circ} \mathrm{C}$ or more at any time. For a Class II building Tupp $=\mathrm{T}_{\text {comf }}+7^{\circ} \mathrm{C}$. In the Camden Passive House, the Threshold/Upper limit exceeded for 1 occupied hour.

Figure 5 EN15251 Overheating Analysis

In Figure 5 the hourly living room operative temperature is plotted against the running monthly mean average external temperature, for both occupied and unoccupied hours. The comfort temperature, EN 15251 Class II Comfort range, $\mathrm{T}_{\max }$ and $\mathrm{T}_{\text {upp }}$ are all plotted along. As $\mathrm{T}_{\max }$ is always greater than $25{ }^{\circ} \mathrm{C}$, the PHPP metric of hours above $25{ }^{\circ} \mathrm{C}$, overestimates the frequency of overheating compared to Criteria 2 of EN 15251. Conversely as $\mathrm{T}_{\max }$ is less than $28{ }^{\circ} \mathrm{C}, 57 \%$ of the summer the CIBSE $28^{\circ} \mathrm{C}$ metric underestimates the frequency of overheating compared to Criteria 2 of EN 15251.

In the first year of monitoring The Camden Passive house therefore failed the PHPP and CIBSE over heating criteria as well as 3 of the 3 EN 15251 over heating criteria. This level of over heating would normally be regarded as unacceptable. When questioned the residents report that they enjoy the warm summer temperatures saying that overheating was not a problem, and when completing a BUS survey reported that summer temperatures can be too cool. The living room windows are designed with a secure tilt opening mechanism, to allow night ventilation without compromising security. When questioned about the use of night ventilation the residents responded they had experimented with leaving the windows in the locked open tilt position but found it led to "overcooling". 
The summer temperature performance of the dwelling is easily understood. The higher than expected internal gains coupled with the as designed solar gain and summer ventilation rate lead to the higher summer temperatures. To reduce the $\%$ of hours above $25{ }^{\circ} \mathrm{C}$ to below $10 \%$, with the measured internal gains, the average summer window ventilation rate needs to be increased from $0.14 \mathrm{ach}^{-1}$ to approximately $0.5 \mathrm{ach}^{-1}$. Figure 4 shows that at present the occupants are choosing to open windows sufficiently to ventilate the dwelling to $0.5 \mathrm{ach}^{-1}$ and above only when daily average external temperature is the order of $20{ }^{\circ} \mathrm{C}$. To maintain the dwelling below $25^{\circ} \mathrm{C}$, the occupants should follow this increased window opening regime at lower external temperatures. Of the 1000 hours in summer when the living room temperature was greater than $25{ }^{\circ} \mathrm{C}, 91 \%$ occurred when it was less than $25{ }^{\circ} \mathrm{C}$ outside, ( $81 \%$ occurring when external temperature less than $22{ }^{\circ} \mathrm{C}$ ) suggesting that greater window opening, (or higher MVHR ventilation rates with summer bypass), when living room temperatures exceeded $25^{\circ} \mathrm{C}$, would be a successful strategy in reducing living room temperatures below $25{ }^{\circ} \mathrm{C}$. In contrast, of the 1000 hours in summer when the living room temperature was greater than $25{ }^{\circ} \mathrm{C}$, only $14 \%$ occurred when solar radiation (global horizontal) was greater than 500 $\mathrm{W} / \mathrm{m}^{2},\left(20 \%\right.$ occurring when solar radiation greater than $\left.400 \mathrm{~W} / \mathrm{m}^{2}\right)$, suggesting that increased ventilation may be more effective than increased shading in reducing overheating.

\subsection{Re commissioning and testing of the MVHR system}

The MVHR system was recommissioned and tested in June 2011, prior to the commencement of the monitoring period. The originally specified G4 intake filter was replaced with an F8 filter, the G4 extract filter was replaced with a clean G4. Tables 5 shows the design extract and supply rate for each room, and the actual rates measured for the $3 \mathrm{MVHR}$ fan settings. The system was found to meet the Passive House standard of less than $10 \%$ balance deviation. The fans speed percentages are the settings from the PAUL Thermos 200 air handler control system. These show that more effort is required from the intake/supply fan than from the extract/ exhaust fan for a given volume of air. The electrical power consumption of the MVHR at 4 fan speed settings was measured, with the clean F8 filter in place.

Table 5 MVHR System; Design and measured air flow and electrical consumption

The average monthly energy consumption of the MVHR system is $23 \mathrm{kWh}$, corresponding to an average power consumption of $36 \mathrm{~W}$. Comparison with the measured flow rates as a function of fan speed and electricity consumption would imply an average fan speed between 2 and 3 with a volume flow of approximately $114 \mathrm{~m} 3 / \mathrm{hr}$. The MVHR was set up to deliver $130 \mathrm{~m}^{3} / \mathrm{hr}$, or $36 \mathrm{l} / \mathrm{s}$, which is an air change rate of $0.48 \mathrm{ach}^{-1}$. 
Average $\mathrm{CO}_{2}$ concentrations, Figure 6 in the living room are 700ppm, with an average evening peak of $815 \mathrm{ppm}$. Average Master bedroom concentrations peak during the night $1085 \mathrm{ppm}$. Bedroom $\mathrm{CO}_{2}$ concentrations are below 1000ppm 78\% of the time, between 800 and $1000 p p m ~ 22 \%$ of the time, and above 1000pm 22\% of the time. The dwelling was designed to meet EN 13779 [33] category IDA3, "moderate or satisfactory", that is a $\mathrm{CO}_{2}$-level above the level of outdoor air by $600 \mathrm{ppm}$ to $1000 \mathrm{ppm}$. To meet IDA3 in a bedroom with sleeping occupants requires a ventilation rate greater than $12 \mathrm{~m}^{3} / \mathrm{hr} /$ person, which is met by the MVHR ventilation rate. Assuming an outside $\mathrm{CO}_{2}$ level of 400ppm, indoor levels of $\mathrm{CO}_{2}$ should be below $1400 \mathrm{ppm}$, which is exceeded for only 127 hours, or $1 \%$ of the time in the first year of monitoring. Bedroom $\mathrm{CO}_{2}$ levels of between 800 to 1000ppm are suggested to be an indicator of an appropriate ventilation rate

[34]. It is noted that the bedroom $\mathrm{CO}_{2}$ concentration exceeds $1000 \mathrm{ppm}$, and could be reduced by increasing the MVHR ventilation rate, which is currently set at the lowest of 3 possible settings. The design of the dwelling was chosen to meet IDA3 rather than IDA2 (good, CO2< 1000ppm) to ensure that RH levels in winter were not too low, i.e. below $30 \%$. It is noted that $\mathrm{CO}_{2}$ concentrations in bedrooms in naturally ventilated dwellings also often exceed 1000ppm, in a recent Danish study [35] of naturally ventilated bedrooms, only $32 \%$ had night time average $\mathrm{CO}_{2}$ concentrations below 1000ppm.

The average decay in $\mathrm{CO}_{2}$ in the mornings when the bedroom is unoccupied, allows a simple air change rate to be calculated, by tracer gas decay method. The concentration of $\mathrm{CO}_{2}$ at time $t, \mathrm{C}_{0}(\mathrm{t})$ can be calculated using Eqtn 3, [36]

$\operatorname{Co}(t)=(C i-\operatorname{Cext})^{\star} \exp (-\lambda t)+\operatorname{Cext} \quad$ Eqtn 3 where $C_{e x t}$ is the external concentration, $C_{i}$ the initial concentration, and $\lambda$ the air change rate. Hence $\ln (\mathrm{Co}-\mathrm{Cext})=\ln (\mathrm{Ci}-\mathrm{Cext})-\lambda^{\star} \mathrm{t} \quad$ Eqtn 4

In Figure $7 \ln [(\mathrm{Ci}-\mathrm{Cext}) /(\mathrm{Co}-\mathrm{Cext})]$ is regressed against time $\mathrm{t}$, the slope giving the air change rate $\lambda$. As internal doors are generally open and the MVHR is always on, inter room air flow is high and the bedroom decay may be used as an indicator of whole house air change rate. The average air change rate from 7 am to $2 \mathrm{pm}$ is $0.43 \mathrm{ach}^{-1}$, or $116 \mathrm{~m}^{3} / \mathrm{hr}, 32.2 \mathrm{l} / \mathrm{s}$.

Figure 6 Average hourly profile of Master Bedroom Room $\mathrm{CO}_{2}$ concentration Figure 7 Estimation of average ventilation rate from decay or Master Bedroom average $\mathrm{CO} 2$ concentration

The ventilation rate measured by the $\mathrm{CO}_{2}$ decay, and the flow rates measured at the MVHR unit are in close agreement. The measured average ventilation rate of $32 \mathrm{l} / \mathrm{s}$ and the measured average power consumption 
of $36 \mathrm{~W}$, results in a measured specific fan power of $1.1 \mathrm{~W} / / \mathrm{s}$ or electric power consumption, $\mathrm{P}_{\mathrm{el}}$ of 0.31 $\mathrm{Wh} / \mathrm{m}^{3}$ for the MVHR system. The Passive House certification for the Paul Thermos MVHR quotes a $P_{\mathrm{el}}$ of $0.31 \mathrm{Wh} / \mathrm{m}^{3}$. The thermal efficiency of the MVHR system, $\eta_{H R \text { eff, was calculated by measuring the air }}$ temperature in the extract, intake and exhaust ducts, the electrical power consumption and the air flow rate. Thermal efficiency was calculated using Equation 5:

$\eta_{H R \text { eff }}=\left(\left(T_{E X T}-T_{E X H}\right)+P_{e l} / m \cdot c_{p}\right) /\left(T_{E X T}-T_{I N T}\right)$ Eqtn. 5

where;

$\mathrm{T}_{\mathrm{EXT}}=$ Extract Temperature $\mathrm{K}$

$\mathrm{T}_{\mathrm{EXH}}=$ Exhaust Temperature $\mathrm{K}$

$\mathrm{T}_{\mathrm{INT}}=$ Intake Temperature $\mathrm{K}$

$\mathrm{P}_{\mathrm{el}}=$ Electric power consumption of Fan $\mathrm{Wh} / \mathrm{m}^{3}$

$\mathrm{m}=$ Air flow $\mathrm{kg} / \mathrm{hr}$

$\mathrm{C}_{\mathrm{p}}=$ Specific heat capacity of air $1005 \mathrm{~J} / \mathrm{kgK}$

The average measured thermal efficiency, $\eta_{H R}$, eff , of the MVHR during the winter heating season, based on an average air supply of $32 \mathrm{l} / \mathrm{s}$, was $82 \%$, compared to the designed and certified value of $92 \%$. For Passive House certification $\mathrm{P}_{\mathrm{el}}$ should be less than $0.45 \mathrm{Wh} / \mathrm{m}^{3}$ and $\eta_{\mathrm{HR}}$, eff should be greater than $75 \%$, hence although the measured heat recovery efficiency performance is slightly worse than expected it still meets Passive House standards.

\subsection{Comparison with PHPP design targets}

The Passive House Planning Package (PHPP) was used as the certification tool for the house; the estimated annual heating demand was $13.2 \mathrm{kWh} / \mathrm{m}^{2}$. This was calculated using a standard PHPP GB London weather file and standard design assumptions about internal heat gains and internal temperature and blind use. In the winter of 2011/12 the measured space heat input was $1220 \mathrm{kWh},\left(12.1 \mathrm{kWh} / \mathrm{m}^{2}\right)$.

For comparison with the measured data the PHPP assessment was recalculated using monitored heat gains, onsite weather conditions, monitored internal temperature, measured MVHR efficiency and observed occupant blind usage. The co heating test suggested that the fabric heat loss was close to the design specification so this was not adjusted. 
Table 6 Original PHPP Design Calculation; Space Heating Demand and As Measured PHPP Design Calculation

Internal heat gains are calculated as per PHPP methodology, dwelling electricity consumption, excluding MVHR consumption is $3.5 \mathrm{~W} / \mathrm{m} 2$, occupancy gain (2 adults) is $0.87 \mathrm{~W} / \mathrm{m}^{2}$. The cold water feed and household evaporation reduce gains by $0.69 \mathrm{~W} / \mathrm{m}^{2}$, an estimated $0.15 \mathrm{~W} / \mathrm{m}^{2}$ from the faulty solar pump is lost to the solar panel, resulting in an estimated internal heat gain of $3.65 \mathrm{~W} / \mathrm{m}^{2}$. The winter internal temperature was set to $22.4{ }^{\circ} \mathrm{C}$. One of the main uncertainties in predicting the space heating of the dwelling is the effect of blind and shade use by the occupants. Interviews with the occupants and site visits show that the occupants often close internal blinds during winter. The blinds in the bedroom are continuously closed to provide privacy. To reflect the blind usage in PHPP the additional shading input was set to $10 \%$.

The predicted as built and normalised PHPP space heating consumption is $1185 \mathrm{kWh}, 11.7 \mathrm{kWh} / \mathrm{m}^{2}$, in very good agreement with the monitored value.

\subsection{Normalised Predicted Space Heating Consumption under standard climate and occupancy conditions}

\section{and observed use of shading}

The predicted space heating requirement under standard conditions, adjusted for as built performance and occupant use of bedroom blinds has been calculated as follows.

- Internal temperature to $20{ }^{\circ} \mathrm{C}$ in winter

- Standard London PHPP TRY weather file

- Internal heat gains $3.65 \mathrm{~W} / \mathrm{m} 2$, (consistent with and occupancy of 2.4 people)

- $\quad 82 \%$ MVHR efficiency

- Observed bedroom blind use in winter

PHPP predicted space heating $=1150 \mathrm{kWh}, 11.4 \mathrm{kWh} / \mathrm{m}^{2}$

\subsection{Performance of the Solar Hot water system}

Using measured solar radiation data in the PHPP the predicted solar hot water production, during the monitoring period is $1190 \mathrm{kWh}$. The monitored solar hot water production was $600 \mathrm{kWh}$. The solar system produced very little heat after March 2012 due to a faulty fuse. It is known that maintenance work took place in February 2012 to adjust the solar system to prevent the solar pump running continuously. The average 
solar fraction, of the domestic hot water demand ( DHW consumption plus storage losses), was 0.27 , due to the above fault, compared to the PHPP predicted value of 0.51 .

\section{$\underline{3.8}$ Time profiles of energy Consumption and activities}

The data from the winter heating season was binned into 5 minute time slots over the 24 hour daily cycle and analysed to obtain the average profile of energy use, temperatures and activities within the home. Such data is useful as it allows the interaction and synchronisation of systems and end uses such as gas use, domestic hot water and space heating to be examined forensically. The profiles are also a valuable research resource for those wishing to simulate the performance of UK low energy dwellings; such simulation requires reliable and realistic profile schedules. In Figure 8 there is a clear peak in DHW consumption between 6 am and 8 am associated with morning showering. Space heating is controlled by a timed programmer and takes place between 6 am and $9 \mathrm{pm}$ in the evening. The peak in gas consumption at $5 \mathrm{am}$ in the morning is associated with heating the hot water cylinder ready for morning demand. Water consumption in the first year was 71,200 litres, corresponding to an average daily water consumption of 195 litres or 98 litres per person per day. This can be compared to average metered UK water use of 150 litres per person per day [37]. In terms of when the water is consumed $40 \%$, is used between 6am to $9 \mathrm{am}$; there is a smaller peak from $9 \mathrm{pm}$ to 1 am, accounting for $25 \%$ of daily consumption, presumably associated with bathing and dish washer use.

The profile of electricity consumption, Figure 9 , is as expected with the minimum occurring at 5 am in the morning, and then increasing throughout the day peaking at 9pm. Figure 10 splits electricity consumption by end use. Kitchen socket use peaks at breakfast and evening meal times. Upstairs living room lights and sockets peak in the evening. It is notable that the minimum average consumption at 5 am is still $200 \mathrm{~W}$. The profile of the MVHR consumption is very flat with no evidence of regular switching to boost mode synchronised with morning hot water use or evening cooking. The Electricity consumption can be compared to that of the recent EST, UK electricity use study [21].

Figure 8 Average hourly profile of Gas, Domestic hot water and Space Heating Consumption Figure 9 Average hourly profile of Electricity Consumption with average UK (EST study) profile Figure 10 Average hourly profile of Electricity Consumption split by use

\subsection{Standardised Temperature, Relative Humidity and Vapour Pressure Excess}

In order to normalise for the weather conditions during the monitoring period and to facilitate comparison with data from other studies and datasets, the standardised temperature and relative humidity in the test house were calculated according to the Warmfront methodology $[38,39]$. The indoor temperature is regressed against the outdoor temperature, including quadratic terms of outdoor temperature to allow for non-linearity 
of the relationship. From the resulting dwelling-specific regression equation, we derived the predicted indoor temperature and its standard error at $5{ }^{\circ} \mathrm{C}$ outdoor temperature. Data was excluded from any day when the maximum temperature was above $15{ }^{\circ} \mathrm{C}$ and from any period of monitoring, if the coldest day during that period had a maximum temperature above $7^{\circ} \mathrm{C}$. For the living room data for the daytime hours of 8 a.m. to 8 p.m. is used and for bedroom the night time hours of $8 \mathrm{pm}$ to $8 \mathrm{am}$.

The standardised temperature in the living room and bedroom were $21.5^{\circ} \mathrm{C}, 19.5^{\circ} \mathrm{C}$ respectively. The empirical relationship between standardised temperature and building energy efficiency, (defined as dwelling heat loss divided by efficiency of primary heating system), derived from the Warmfront database of over 1500 UK dwellings, predicts that the Camden Passive House would be expected to have a standardised living room and bedroom temperature of $19.1^{\circ} \mathrm{C}$, and $17.3^{\circ} \mathrm{C}$ respectively. It can be seen that the dwelling is substantially warmer. Only 3 dwellings in the Warmfront database had an energy efficiency of less than 100 $\mathrm{W} / \mathrm{K}$. The data suggests that the relationship from the Warmfront database may underestimate the standardised temperatures of very low heat loss and passive houses. This is an important finding as the Warmfront relationship has been used extensively to estimate the temperature gains and subsequent health impact of refurbishing dwellings to higher levels of insulation. The standardised relative humidity in the living room and bedroom were calculated using the Warmfront methodology, was found to be $39 \%$ and $46 \%$ respectively. These low values of standardised $\mathrm{RH}$ would suggest a low risk of mould growth and indicate that the MVHR system was providing an adequate ventilation rate.

Figure 11 Average hourly profile of Living Room winter Figure 12 Average hourly profile of Master Bedroom winter Figure 13 Average hourly profile of Living Room summer temperature Figure 14 Average hourly profile of Master Bedroom Room summer temperature

The temperature profile in the living room is very stable, with $80 \%$ of the readings between $19{ }^{\circ} \mathrm{C}$ and $24{ }^{\circ} \mathrm{C}$, the average daily temperature range is between $21^{\circ} \mathrm{C}$ and $22{ }^{\circ} \mathrm{C}$. The master bedroom is slightly colder with $80 \%$ of the readings between $17.7^{\circ} \mathrm{C}$ and $22{ }^{\circ} \mathrm{C}$; the average daily temperature range is between $19.6{ }^{\circ} \mathrm{C}$ and $20.4{ }^{\circ} \mathrm{C}$. Relative humidity in the habitable rooms is very stable with $80 \%$ of readings in the living room lying between 32 and $48 \%$. Only the bathroom experiences high peaks of $\mathrm{RH}$, attributable to morning and evening bathing, however the $90^{\text {th }}$ percentile peak of $\mathrm{RH}$ in the bathroom is still below $70 \%$. Daily, weekly and monthly average $\mathrm{RH}$ in all rooms, suggest the risk of mould growth is very low. Average vapour pressure excess in the living room, master bedroom and kitchen are 292Pa, $328 \mathrm{~Pa}$ and $283 \mathrm{~Pa}$ respectively. Vapour pressure excess peaks at 500Pa in the living room and kitchen but these evening peaks are in the $90^{\text {th }}$ percentile of occurrence. The relative humidity and $\mathrm{CO}_{2}$ concentrations in the living room and bedroom indicate good IAQ and appropriate ventilation rates. The average summer (May to 
September) temperature profile in the living room is very stable, fluctuating between 23.5 and $24.5^{\circ} \mathrm{C}$. The $95^{\text {th }}$ percentile of summer living room temperatures is above $28{ }^{\circ} \mathrm{C}$ and occurs between 3 and $7 \mathrm{pm}$, with the maximum at $5 \mathrm{pm}$. The $90^{\text {th }}$ percentile of summer living room temperatures is above $26^{\circ} \mathrm{C}$ and occurs between Midday and Midnight, with the maximum at 5pm. Hence the living room temperature in 1 in 10 summer afternoons and evenings is over $26^{\circ} \mathrm{C}$. The master bedroom temperature profile in summer is very stable, with average temperature between 21 and $22{ }^{\circ} \mathrm{C}$, rarely breaking through $24^{\circ} \mathrm{C}$.

\subsection{Forensic investigation and troubleshooting}

During the monitored period a number of faults and sub optimal performance issues were spotted, these were then investigated on site by the architects, M\&E consultants and service engineers provided by the product manufactures. A site visit in June 2011 noted that the solar thermal panels had been installed with an incorrect orientation, this was corrected. Analysis of the daily profiles of domestic hot water consumption, solar hot water production and gas consumption, suggested that the DHW system had not been optimised to make use of solar input. Gas consumption was high even though the solar input to the cylinder was greater than the hot water consumption. No space heating was being used. In August and September total solar production was $316 \mathrm{kWh}$, while DHW consumption was only $135 \mathrm{kWh}$; however $84 \mathrm{kWh}$ of gas was still consumed.

The daily gas peak, due to the hot water charging being enabled at midday irrespective of solar input was in part due to a diverter valve (DHW charging circuit) having been set to reheat the whole 250 litres DHW cylinder rather than top 80 litres, as is recommended for solar connected units. This setup was rectified on the $14^{\text {th }}$ of Nov 2011. In autumn and early winter the electrical consumption of the boiler and associated pumps was very high, accounting for approximately $50 \%$ of the total dwelling electricity consumption. The high electrical consumption of the boiler was found to be due to 2 pumps running continuously, the solar pump and the heating pump. The solar pump was running even though not called for by the solar controls. The heating pump ran continuously even when the boiler was switched to hot water only. The solar pump had been incorrectly wired to the solar control system; the solar pump cable was not in the correct solar pump socket, but in an identical adjacent "permanent live" socket. The heating pump fault was attributed to the installation of a non standard boiler controller board, fitted in order to allow the heating to be controlled by the MVHR system. This controller had been incorrectly programmed to work with the boiler. These problems were resolved on site and the effect is seen in the reduction of boiler and pumper electricity consumption in February. 
In December and January, when there was a space heating requirement in the dwelling, the monitoring system identified that the heater battery in the MVHR supply duct was not heating the supply air. The heat meter on the heater battery circuit was detecting small heat consumption possibly from heat leaking through a closed or "stuck" valve, but there was no impact on the air temperature. A site visit on the $17^{\text {th }}$ of January found that a valve on the heater battery had been closed, once opened the duct temperatures rose as expected. Prior to the $17^{\text {th }}$ on January the MVHR heater battery had not been working correctly, with the heat output not being delivered to the supply air. Site visits in the autumn of 2011 had previously identified that the towel rail in the second bedroom was not working correctly.

\subsection{Discussion}

Data from the first monitored heating season of the Camden Passive House provides a valuable insight into the performance of a low energy dwelling in the UK. Problems with the installation and control of the DHW and heating system were identified and rectified. These teething problems must be seen in the context of the Camden House being a very carefully designed, constructed and commissioned dwelling, which has received the enthusiastic and knowledgeable attention of specialist contractors and consultants, which had already undergone a more rigorous and "softer landing" and hand over than a standard volume house builder could deliver. The need for thorough testing and commissioning of heating and DHW systems is evident. The danger of modifying or adapting systems, for example changing the boiler controller to interface with the MVHR system can be difficult. The first monitored heating season can be viewed in part as a period during which problems were identified and resolved. However this was the second heating season the house had been occupied, without detailed monitoring and investigation, some of theses installation issues would not have been found, resulting in sub optimal performance.

- The dwelling is meeting the Passive House design target of space heating demand $<15 \mathrm{kWh} / \mathrm{m}^{2}$. $\left(12.1 \mathrm{kWh} / \mathrm{m}^{2}\right)$

- The dwelling just failed to meet the total primary energy target $<120 \mathrm{kWh} / \mathrm{m}^{2}$. $\left(124 \mathrm{kWh} / \mathrm{m}^{2}\right)$.

- Savings of $500 \mathrm{kWh}$ were identified by rectifying problems with solar thermal heating and domestic hot water system. Allowing for these modifications the primary energy demand of the dwelling would have been reduced to $113 \mathrm{kWh} / \mathrm{m}^{2}$.

- The level of internal gains is $3.65 \mathrm{~W} / \mathrm{m}^{2}, 43 \%$ more than the standard value of $2.1 \mathrm{~W} / \mathrm{m}^{2}$ assumed for a Passive house. UK designers may need to assume higher internal gains when using PHPP 
- The measured space heating consumption of the dwelling is in good agreement with the as built normalised performance predicted by PHPP. For privacy reasons the occupants reported and were observed to use blinds in the bedrooms in winter.

- Distribution and storage losses from the heating and DHW are or the order of $10.7 \mathrm{kWh} / \mathrm{m}^{2}$.

- A co-heating test measured the fabric and infiltration heat loss of the dwelling to be $56 \mathrm{~W} / \mathrm{K} \pm 5 \mathrm{~W} / \mathrm{K}$. This compares favourably to the design figure of $66 \mathrm{~W} / \mathrm{K}$.

- $\quad$ The heating system appears to be used in an ON or OFF mode rather than under thermostatic control

- The house is very comfortable in winter, with the occupants choosing an average winter living room temperature of $22.4{ }^{\circ} \mathrm{C}$.

- $\quad$ Summertime overheating is observed. The house fails CIBSE, PHPP and EN 15251 overheating criteria, however the occupants report enjoying the warm summer conditions, and cool summer evenings on the terrace and do not complain of overheating. PHPP is found to be a good predictor of summer over heating risk. For the high internal gains observed, greater summer window opening or increased blind use would be required to avoid exceeding $25^{\circ} \mathrm{C}$. Window opening is observed to be a function of external temperature. The occupants do not plan to modify their use of blinds or ventilation patterns.

- Indoor air quality, in terms of relative humidity and $\mathrm{CO}_{2}$ is very good, with a very low risk of mould growth predicted even in bathrooms and kitchen.

The monitoring system is performing well, the dataset allows the performance of the house to be understood and examined in detail. The main factors that still need to be estimated are the actual solar gain, with the gain through windows being determined using tabulated solar heat gain coefficients and assumptions on shading and occupant blind use rather than direct measurement. There is also uncertainty in the heat output of the towel rail in the guest en suite. One oversight is that the monitoring system measures the DHW consumption and the heat input to the cylinder from the solar thermal system, but the heat input to the cylinder from the boiler and the cylinder temperature are not directly measured. Similarly it would have been preferable to directly measure the total heat output of the boiler, to allow boiler efficiency to be calculated. However the installation of such a monitoring system to the Viessmann system post installation would be very difficult and impractical because this would compromise the warranty.

In terms of user interaction and satisfaction, the dwelling was generally well received by the occupants. A semi structured interview was carried out with one of the occupants in July 2012 [40]. The interview 
consisted of general questions on the occupants and household, and questions on the level of satisfaction with the accommodation, including the facilities, layout, and systems taken from The Survey of English Housing [41] and the English House Condition Survey [42]. A general comfort survey, including indoor air quality, acoustic comfort, thermal Comfort taken from, the CBE Occupant Satisfaction Survey [43]. When asked about the heating controls one occupant reported that they "Did not understand the controls and found them complicated". When asked about summertime thermal comfort the occupant noted "When it gets hot, it gets very hot, but effectively it could be resolved by means of opening windows." The main occupant of the house reported enjoying the warm summer temperatures, and did not regard overheating as being a problem.

The house is built in a high density, urban area, on a heavily over looked site. For reasons of privacy the occupants showed higher than expected use of window blinds in winter, which reduced useful solar gain and increased space heating demand. In summer however the occupants wished to use the terrace and balcony area, connected to the living room, and wished to enjoy the summer view out, leading to less than expected summer shading in the living room. There is some evidence that the occupants interacted poorly with the heating thermostat, leading to some winter over heating. The use of blinds by the occupants in summer could have been improved. When interviewed the occupants reported they did not intend to change their current window opening or blind use behaviour.

\subsection{Conclusions}

The Camden Passive House is one of the lowest energy dwellings ever monitored in the UK with a total metered gas and electricity consumption of $65 \mathrm{kWh} / \mathrm{m}^{2}$ per annum. For comparison comparable UK exemplars are BedZed $90 \mathrm{kWh} / \mathrm{m}^{2}$, The Long House $80 \mathrm{kWh} / \mathrm{m}^{2}$, One Brighton $72 \mathrm{kWh} / \mathrm{m}^{2}$, Princedale Road $63 \mathrm{kWh} / \mathrm{m}^{2}$.

Monitoring is ongoing and with the rectification of faults identified in the first year, future energy consumption could reasonably be expected to be reduced further. In terms of the wider lessons that can be learned from this case study that can inform low energy dwelling design and delivery in the UK, it is clear that the Passive house air tightness standard was successfully met. The measured specific fan power and efficiency of the MVHR also met Passive House standards. 
The commissioning of the MVHR system was found to very good, ventilation rates measured both by testing with a flow hood and long term in use $\mathrm{CO}_{2}$ decay, were close to design targets. The indoor air quality in the dwelling is very good, the vapour pressure excess is low, resulting in low RH. When the dirty G4 filters were changed after 6 months use, no measurable change in flow rate was observed between clean and dirty filters, suggesting no degradation in performance if filters are replaced in the prescribed time scale. However when high performance F8 filters were installed a reduction in supply rates was observed, requiring the system to be re commissioned. The MVHR system and high level of air tightness were delivering both kWh and $\mathrm{CO}_{2}$ savings at the same time as delivering a well ventilated indoor environment.

The case study suggests that with careful design using PHPP and robust testing and commissioning of heating and hot water services UK dwellings with total energy consumption of $60 \mathrm{kWh} / \mathrm{m}^{2}$ should be possible to deliver. A problematic feature of the dwelling's performance is summertime overheating, especially in the living room. The occupants however did not report overheating as being a problem even though commonly used summer time overheating criteria were exceeded. The solar thermal system suffered from installation and reliability issues. The high electricity consumption and heat losses due to the constantly running solar pump, and the malfunctioning of the system post March 2012 mean that the system was not effective in delivering either $\mathrm{kWh}$ or $\mathrm{CO}_{2}$ savings. The internal gains of $3.65 \mathrm{~W} / \mathrm{m}^{2}$ should also be noted, designers using PHPP in the UK may wish to use a higher figure than the standard $2.1 \mathrm{~W} / \mathrm{m}^{2}$. To further improve the performance of low energy dwellings in the UK attention must be paid to the storage and distribution losses of the hot water system.

\section{References}

[1] Feist, W., 2007, Passive Houses in Practice, Darmstadt: Passive House Institute

[2] PASS NET International PassiveHouseDataBase.eu. Establishment of a Co-operation Network of Passive House Promoters (PASS-NET). Vienna 2010

[3] Schnieders J Hermelink A, . CEPHEUS results: measurements and occupants' satisfaction provide evidence for Passive Houses being an option for sustainable building. Energy Policy 34 (2006) pp 151-171. ELSEVIER

[4] PassiveHaus Trust 2012. Accessed September 2012

ttp://www.passivhaustrust.org.uk/UserFiles/File/Projects/Awards2012/Presentations/2012UKPHAwards_Princedale \%20Road.pdf

[5] McLeod, R.S., Hopfe, C.J., Rezgui, Y., 2010. Passivhaus and PHPP - Do continental design criteria work in a Welsh climatic context? 3rd BauSIM Conference, 22.-24. September 2010, Vienna, Austria

[6] HM Government 2010. Approved Document L1A: Conservation of fuel and power (New dwellings) (2010 edition) republished December 2010. ISBN: 9781859463246

[7] Department for Communities and Local Government (DCLG), 2006, Code for Sustainable Homes: A step-change in sustainable home building practice, Wetherby, Communities and Local Government Publications

[8] Department for Communities and Local Government (DCLG), 2008, Definition of Zero Carbon Homes and NonDomestic Buildings: Consultation Wetherby, Communities and Local Government Publications

[9] Zero Carbon Hub (ZCH), 2009, Defining a Fabric Energy Efficiency Standard for Zero Carbon Homes, London: Zero Carbon Hub 
[10] Wingfield, J., Bell, M., Miles-Shenton, D., South, T., Lowe, R.J., 2009, Evaluating the Impact of an Enhanced Energy Performance Standard on Load-Bearing Masonry Construction - Final Report: Lessons From Stamford Brook - Understanding the Gap between Designed and Real Performance, Leeds, UK, Leeds Metropolitan University

[11] G. Branco, G., Lachal, B., Gallinelli, P., Weber, W., 2004, Predicted versus observed heat consumption of a low energy multifamily complex in Switzerland based on long-term experimental data, Geneva:

Centre universitaire d'étude des problèmes de l'énergie (CUEPE)

[12] Clevenger, C., Haymaker, J., 2006, The Impact of the Occupant on Building Energy Simulations, Joint International Conference on Computing and Decision Making in Civil and Building Engineering, Montreal, Canada

[13] Vringer, C.R., 2005, Analysis of the Requirements for Household Consumption, Environmental Assessment Agency

[14] Gram-Hanssen, K., Larsen, T., Knudsen, H., Kanstrup, A., Christiansen, E., Mosgaard, M., Brohus, H., Heiselberg, P., Rose, J., 2010, Occupants Influence on the Energy Consumption of Danish Domestic Buildings : state of the art, Aalborg: Aalborg University, 77 p. (DCE Technical Reports; 110)

[15] Gill, Z. M., Tierney M.J., Pegg, I. M , Allan, N. Measured energy and water performance of an aspiring low energy/carbon affordable housing site in the UK. Energy and Buildings 43 (2011) 117-125. Elsevier

[16] Shrubsole, C, Ridley, I, Biddulph, P, Milner, J, Vardoulakis, S, Ucci, M, Wilkinson, P., Chalabi, Z., Davies, M. Indoor PM2.5 exposure in London's domestic stock: modeling current and future exposures following energy efficient refurbishment, Atmospheric Environment, Available online 5 September 2012, ISSN 1352-2310, 10.1016/j.atmosenv.2012.08.047.

[17] Wilkinson,P., Smith,K., Davies,M., Adair,H., Armstrong,B., Barrett,M., Haines,A., Hamilton,I., Oreszczyn,T., Ridley,I., Tonne,C., Chalabi,Z. Public health effects of strategies to reduce green house-gas emissions: household energy. The Lancet 374, . ISSN: 0140-6736

[18] Robert Lowe, R. Johnston D. A field trial of mechanical ventilation with heat recovery in Local Authority, low rise housing: Final Report. November 1997. Centre for the Built Environment. Leeds Metropolitan University.

[19] Lewis, S. Camden Passivhaus, London's First Passivhaus. 15th International Passive House Conference Innsbruck 2011

[20] EST (2008) CE298 Monitoring energy and carbon performance in new homes. Energy Saving Trust. EST. UK: 2008. [cited 2012 Available from: http://www.energysavingtrust.org.uk/business/Global-

Data/Publications/Monitoring-energyand-carbon-performance-in-new-homes-CE298

[21] Powering the Nation Household electricity-using habits revealed. Energy Saving Trust 2012. http://www.energysavingtrust.org.uk/Publications2/Corporate/Research-and-insights/Powering-the-nationhousehold-electricity-using-habits-revealed

\section{[22] OFGEM 2012 www.ofgem.gov.uk/Markets/RetMkts/Compl/Consumption/Pages/ConsumptionReview.aspx}

[23] DECC 2010 Sub-national energy consumption statistics, DECC.

http://www.decc.gov.uk/en/content/cms/statistics/regional/regional.aspx

[24] Clarke, Alan. Grant, Nick. The importance of hot water system design in the Passivhaus. International Passivhaus Conference. 2010

[25] Bainbridge J. 2011. Do buildings that are built according to sustainability principles and to a high environmental standard deliver a sustainable living solution to their occupants? A Case Study: One Brighton. MSc dissertation EDE University College London 2011

[26] Wingfield j, Johnston D, Miles- Shenton D, Bell M. Whole house heat loss test method (Co-heating) (2010). Centre for the Built Environment. Leeds Metroploitan University. Leeds. UK

[27] Stamp S. Co-heating Test of Camden Passivhaus. (2013) Energy Institute. University College London. UK.

[28 ] DEFRA The Government's Standard Assessment Procedure for Energy Rating of Dwellings. Published on behalf of DEFRA by: BRE Garston, Watford WD25 9XX. 2008

[29] Fox J. A study of Occupant Controlled Ventilation within UK Dwellings. PhD Thesis. University College London UK. 2008.

[30] Dubrul C. (1988) 'Inhabitant Behaviour with Respect to Ventilation- a Summary Report of IEA Annex V111' Technical Note 23, IEA ECBCS Annex V Air Infiltration and Ventilation Centre (AIVC) Executive Committee, University of Namur, Belgium.1988 by the Air Infiltration and Ventilation Centre (AIVC) 
[31] CIBSE (2006), Guide A: Environmental design, Chartered Institute of Building Services Engineers, London.

[32] BS EN 15251 (2007), Indoor environmental input parameters for design and assessment of energy performance of buildings addressing indoor air quality, thermal environment, lighting and acoustics, British Standards Institute, London.

[33] EN 13779:2007. Ventilation for non-residential buildings. Performance requirements for ventilation and roomconditioning systems. CEN 2007

[34] Good Homes Alliance. Ventilation and good indoor air quality in low energy homes; Finding proven good practice. London UK. 2011

[35] Bekö G, Lund T, Nors F, Toftum J, Clausen G. Ventilation rates in the bedrooms of 500 Danish children. Building and Environment 45 (2010) pp2289-2295 Elsevier Ltd

[36] Laussmann D, Helm D, (2011). Air Change Measurements Using Tracer Gases: Methods and Results. Chapter 14, p 375. Significance of air change for indoor air quality, Chemistry, Emission Control, Radioactive Pollution and Indoor Air Quality, Dr. Nicolas Mazzeo (Ed.), ISBN: 978-953-307-316-3, InTech.

[37] DEFRA 2008. Future Water The Government's water strategy for England. Cm 7319. DEFRA . HM Government 2008

[38] Oreszczyn,T., Hong,S.H., Ridley,I., Wilkinson,P., Warm Front Study Group (2006). Determinants of winter indoor temperatures in low income households in England. Energy and Buildings 38(3), 245-252. ISSN: 0378-7788

[39] Oreszczyn,T., Ridley,I., Wilkinson,P., Hong,S.H., Warm Front Study Group (2006). Mould and Winter Indoor Relative Humidity in Low Income Households in England. Indoor and Built Environment 15(2), 125-135. ISSN: 1420$326 x$.

[40] Gautier S. Comfort survey and semi-structured interview. UCL Energy Institute. For Bere Architects 2012

[41] Survey of English Housing, 1993/94-2007/08 (SEH15; SEH) HMSO. UK June 2010

[42] English Housing Survey, 2008-2009: Household Data (EHS) HMSO UK November 2010

[43] CBE Occupant Satisfaction Survey. http://www.cbe.berkeley.edu/research/survey links.htm. Accessed Jan 2013

\section{Tables and Figures}

Table 1 Electricity Consumption (kWh)

Table 2 Gas consumption, Space Heating and Domestic Hot Water consumption (kWh)

Table 3 Average Room Temperatures ${ }^{\circ} \mathrm{C}$ and Relative Humidity $\%$ and Weather Conditions

Table 4 Summer time Over-heating, \% of Hours over $25^{\circ} \mathrm{C}$ and $28{ }^{\circ} \mathrm{C}$

Table 5 MVHR System; Design and measured air flow.

Table 6 Original PHPP Design Calculation; Space Heating Demand and As Measured PHPP Design Calculation

Figure 1 Photograph of south façade of completed house. (Source Tim Crocker)

Figure 2 Distribution of hours the heating system operated as a function of living room temperature.

Figure 3 Summer Heat Loss and Window Opening

Figure 4 Comparison of measured and PHPP predicted overheating frequency

Figure 5 EN15251 Overheating Analysis

Figure 6 Average hourly profile of Master Bedroom Room $\mathrm{CO}_{2}$ concentration

Figure 7 Estimation of average ventilation rate from decay or Master Bedroom average $\mathrm{CO} 2$ concentration

Figure 8 Average hourly profile of Gas, Domestic hot water and Space Heating Consumption

Figure 9 Average hourly profile of Electricity Consumption with average UK (EST study) profile

Figure 10 Average hourly profile of Electricity Consumption split by use

Figure 11 Average hourly profile of Living Room winter

Figure 12 Average hourly profile of Master Bedroom winter

Figure 13 Average hourly profile of Living Room summer temperature

Figure 14 Average hourly profile of Master Bedroom Room summer temperature

\section{Acknowledgements}

The monitoring and analysis of the Camden Passive House was funded by the Technology Strategy Board, Building Performance Evaluation Programme. Commissioning and investigation of the heating and hot water system was carried out by Alan Clark. Commissioning of the MVHR system was carried out by Andrew Farr. The Co heating test was performed by Samuel Stamp, 
and the occupant survey by Stephanie Gautier. The authors wish to express their thanks to the owners of the test house for their kind co operation during the monitoring period.

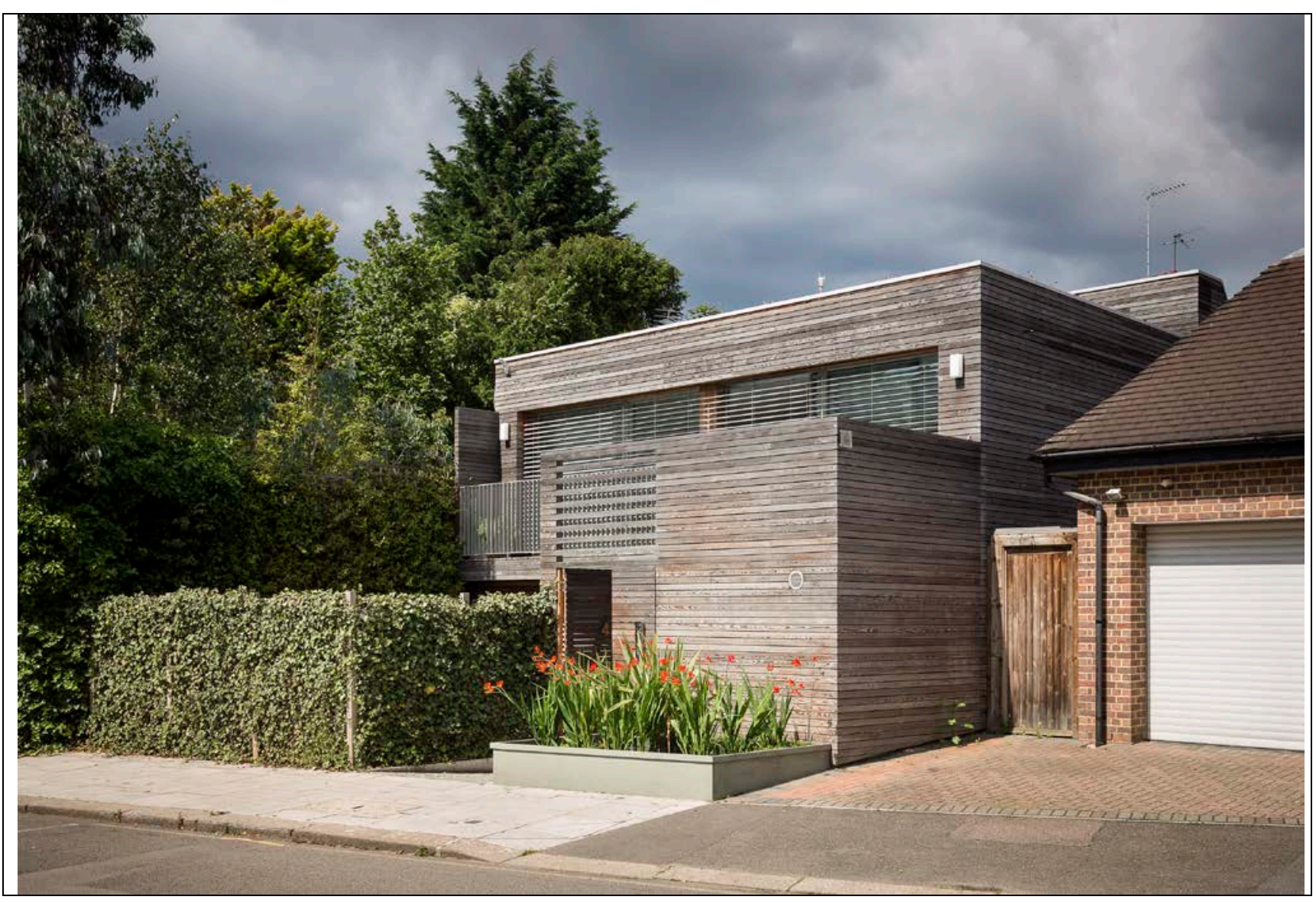


Table 1 Electricity Consumption (kWh)

\begin{tabular}{|c|c|c|c|c|c|c|c|}
\hline & Lights & Sockets & Cooking & Blinds & $\begin{array}{l}\text { Boiler and } \\
\text { Pumps }\end{array}$ & MVHR & $\begin{array}{l}\text { Total } \\
\text { Electricity }\end{array}$ \\
\hline Aug 11 & 90 & 121 & 2 & 2 & 125 & 21 & 380 \\
\hline Sep 11 & 59 & 117 & 2 & 0 & 141 & 23 & 365 \\
\hline Oct 11 & 57 & 109 & 0 & 0 & 127 & 21 & 333 \\
\hline Nov 11 & 53 & 111 & 1 & 0 & 97 & 22 & 303 \\
\hline Dec 12 & 66 & 126 & 3 & 0 & 124 & 28 & 369 \\
\hline Jan 12 & 81 & 137 & 4 & 0 & 92 & 26 & 360 \\
\hline Feb 12 & 38 & 117 & 1 & 0 & 50 & 23 & 227 \\
\hline Mar 12 & 38 & 94 & 0 & 0 & 32 & 21 & 184 \\
\hline Apr 12 & 47 & 128 & 3 & 0 & 37 & 23 & 234 \\
\hline May 12 & 38 & 107 & 2 & 0 & 35 & 28 & 201 \\
\hline Jun 12 & 23 & 97 & 1 & 1 & 37 & 27 & 178 \\
\hline Jul 12 & 34 & 130 & 3 & 6 & 35 & 24 & 225 \\
\hline Total & 623 & 1393 & 23 & 9 & 933 & 289 & 3359 \\
\hline$\%$ & 19 & 41 & 1 & 0 & 28 & 9 & \\
\hline
\end{tabular}

Table 2 Gas consumption, Space Heating and Domestic Hot Water consumption (kWh)

\begin{tabular}{|c|c|c|c|c|c|c|c|}
\hline & $\begin{array}{c}\text { DHW } \\
\text { Consumed }\end{array}$ & $\begin{array}{c}\text { Solar } \\
\text { Produced }\end{array}$ & $\begin{array}{c}\text { MVHR } \\
\text { Space } \\
\text { Heat }\end{array}$ & $\begin{array}{c}\text { Towel Rail } \\
\text { Space } \\
\text { Heat } \\
\end{array}$ & $\begin{array}{c}\text { Total Space } \\
\text { Heat }\end{array}$ & $\begin{array}{l}\text { Distribution } \\
\text { and Storage } \\
\text { Losses }\end{array}$ & $\begin{array}{l}\text { Total } \\
\text { Gas }\end{array}$ \\
\hline Aug 11 & 78 & 167 & 0 & 0 & 0 & 110 & 23 \\
\hline Sep 11 & 73 & 149 & 0 & 0 & 0 & 134 & 64 \\
\hline Oct 11 & 50 & 86 & 1 & 0 & 1 & 104 & 77 \\
\hline Nov 11 & 42 & 17 & 34 & 23 & 57 & 111 & 214 \\
\hline Dec 12 & 87 & 14 & 153 & 218 & 371 & 97 & 601 \\
\hline Jan 12 & 103 & 18 & 217 & 146 & 363 & 87 & 594 \\
\hline Feb 12 & 104 & 17 & 318 & 80 & 398 & 68 & 614 \\
\hline Mar 12 & 63 & 67 & 16 & 6 & 22 & 73 & 101 \\
\hline Apr 12 & 114 & 45 & 76 & 24 & 100 & 79 & 275 \\
\hline May 12 & 84 & 0 & 6 & 3 & 9 & 72 & 183 \\
\hline Jun 12 & 82 & 4 & 36 & 11 & 47 & 78 & 226 \\
\hline Jul 12 & 100 & 5 & 35 & 17 & 52 & 74 & 246 \\
\hline Winter & 449 & 219 & 739 & 473 & 1212 & 539 & 2201 \\
\hline Total & 981 & 589 & 892 & 525 & 1420 & 1085 & 3217 \\
\hline
\end{tabular}

Table 3 Average Room Temperatures ${ }^{\circ} \mathrm{C}$ and Relative Humidity $\%$ and Weather Conditions

\begin{tabular}{|c|c|c|c|c|c|c|c|c|}
\hline & $\begin{array}{l}\text { Living } \\
\text { Room T }\end{array}$ & $\begin{array}{c}\text { Master } \\
\text { Bedroom } \\
T\end{array}$ & $\begin{array}{c}\text { Living } \\
\text { Room } \\
\text { RH }\end{array}$ & $\begin{array}{c}\text { Master } \\
\text { Bedroom } \\
\text { Bed RH }\end{array}$ & $\begin{array}{c}\text { External } \\
T\end{array}$ & $\begin{array}{c}\text { Average } \\
\text { Global Solar } \\
\text { Horizontal } \\
\text { W/m }\end{array}$ & $\begin{array}{c}\text { Degree } \\
\text { Days } \\
\text { (base18) }\end{array}$ & $\begin{array}{c}\text { Kew TRY } \\
\text { Degree } \\
\text { days } \\
\text { (base 18) }\end{array}$ \\
\hline Aug 11 & 24.5 & 23.4 & 49.4 & 55.2 & 16.3 & 164 & 64 & 29 \\
\hline Sep 11 & 24.5 & 24.0 & 50.6 & 58.1 & 15.9 & 157 & 82 & 91 \\
\hline Oct 11 & 25.3 & 22.8 & 43.9 & 52.1 & 13.6 & 111 & 126 & 191 \\
\hline Nov 11 & 20.9 & 19.2 & 50.7 & 57.9 & 9.7 & 43 & 231 & 280 \\
\hline Dec 12 & 21.2 & 19.8 & 43.4 & 47.9 & 6.4 & 31 & 358 & 366 \\
\hline Jan 12 & 21.7 & 20.3 & 41.7 & 47.5 & 6.3 & 38 & 362 & 365 \\
\hline Feb 12 & 22.1 & 19.9 & 34.8 & 41.9 & 4.5 & 68 & 393 & 328 \\
\hline Mar 12 & 23.2 & 19.4 & 37.2 & 47.2 & 9.8 & 183 & 174 & 337 \\
\hline Apr 12 & 21.7 & 18.9 & 39.7 & 49.2 & 8.1 & 152 & 299 & 251 \\
\hline May 12 & 22.4 & 19.7 & 46.9 & 58.2 & 13.1 & 194 & 168 & 145 \\
\hline Jun 12 & 23.6 & 21.0 & 48.3 & 59.5 & 14.5 & 180 & 116 & 77 \\
\hline Jul 12 & 24.8 & 22.5 & 60.1 & 51.1 & 16.4 & 186 & 73 & 16 \\
\hline Total & & & & & & 1508 & 2446 & 2476 \\
\hline $\begin{array}{l}\text { Winter } \\
\text { Average }\end{array}$ & 22.4 & 20.2 & 41.9 & 49.1 & 8.4 & & & \\
\hline $\begin{array}{l}\text { Summer } \\
\text { Average }\end{array}$ & 23.6 & 21.6 & 49.2 & 55.2 & 14.1 & & & \\
\hline
\end{tabular}


Table 4 Summer time Over-heating, $\%$ of Hours over $25^{\circ} \mathrm{C}$ and $28{ }^{\circ} \mathrm{C}$

\begin{tabular}{|l|r|r|r|r|r|r|r|r|}
\hline & \multicolumn{2}{|l|}{ Living room } & \multicolumn{2}{l|}{ Master Bedroom } & \multicolumn{2}{l|}{ Kitchen } & \multicolumn{2}{l|}{ Guest Bedroom } \\
\hline & $>25{ }^{\circ} \mathrm{C}$ & $>28{ }^{\circ} \mathrm{C}$ & $>25^{\circ} \mathrm{C}$ & $>28{ }^{\circ} \mathrm{C}$ & $>25^{\circ} \mathrm{C}$ & $>28^{\circ} \mathrm{C}$ & $>25^{\circ} \mathrm{C}$ & $>2{ }^{\circ} \mathrm{C}$ \\
\hline Aug 11 & 38 & 4 & 11 & 0 & 57 & 5 & 0 & 0 \\
\hline Sep 11 & 25 & 5 & 1 & 0 & 44 & 7 & 0 & 0 \\
\hline Apr 12 & 0 & 0 & 0 & 0 & 1 & 0 & 0 & 0 \\
\hline May 12 & 23 & 1 & 0 & 0 & 25 & 3 & 0 & 0 \\
\hline Jun 12 & 14 & 1 & 1 & 0 & 23 & 2 & 2 & 0 \\
\hline Jul 12 & 35 & 6 & 8 & 0 & 51 & 8 & 7 & 0 \\
\hline Average & 22.5 & $\mathbf{2 . 8}$ & 3.5 & $\mathbf{0 . 0}$ & 33.5 & $\mathbf{4 . 2}$ & 1.4 & $\mathbf{0 . 0}$ \\
\hline
\end{tabular}

Table 5 MVHR System; Design and measured air flow, Electrical Consumption and Fan speed.

\begin{tabular}{|c|c|c|c|c|c|c|c|c|c|c|c|}
\hline \multicolumn{5}{|c|}{ Air distribution balance by rooms $\mathrm{m}^{3} / \mathrm{hr}$} & \multicolumn{7}{|c|}{ Actual measured figures $\mathrm{m}^{3} / \mathrm{hr}$} \\
\hline & \multicolumn{2}{|c|}{$\begin{array}{l}\text { Before } \\
\text { correction }\end{array}$} & \multicolumn{2}{|c|}{ Balanced } & \multicolumn{3}{|c|}{ Fan speed 1} & \multicolumn{2}{|c|}{ Fan speed 2} & \multicolumn{2}{|c|}{ Fan speed 3} \\
\hline Room & Supply & Extract & Supply & Extract & Supply & \multicolumn{2}{|c|}{ Extract } & Supply & Extract & Supply & Extract \\
\hline \multicolumn{12}{|c|}{ Level: Ground } \\
\hline Bedroom1 & 40 & & 40 & & 27 & & & 33 & & 40 & \\
\hline Bedroom2 & 40 & & 40 & & 23 & & & 28 & & 33.5 & \\
\hline Bathroom1 & & 28 & & 24 & & 12 & & & 16.5 & & 21.5 \\
\hline Bathroom2 & & 28 & & 24 & & 13 & & & 47 & & 21 \\
\hline Toilet & & 21 & & 18 & & 11 & & & 14 & & 17 \\
\hline Utility & & 28 & & 17 & & 9 & & & 1.25 & & 15 \\
\hline \multicolumn{12}{|c|}{ Level: First floor } \\
\hline Kitchen & & 47 & & 47 & & 35 & & & 42 & & 55 \\
\hline $\begin{array}{l}\text { Living } \\
\text { room }\end{array}$ & 32 & & 50 & & 37 & & & 45 & & 56 & \\
\hline Totals & 112 & 152 & 130 & 130 & 87 & 80 & & 106 & 102 & 129.5 & 129.5 \\
\hline \multicolumn{5}{|c|}{ Balance deviation from supply/extract mean \% } & \multicolumn{3}{|c|}{8.38} & \multicolumn{2}{|c|}{3.85} & \multicolumn{2}{|c|}{0.00} \\
\hline \multicolumn{5}{|c|}{ Total in $\mathrm{m} 2 / \mathrm{hr}$} & \multicolumn{3}{|c|}{82.81} & \multicolumn{2}{|c|}{104.08} & \multicolumn{2}{|c|}{129.5} \\
\hline & & & & \multicolumn{8}{|c|}{ External and fan settings } \\
\hline & & & & Intake & Exhat & & Intak & & laust & Intake & Exhaust \\
\hline & & & & \multicolumn{3}{|c|}{ Fan speed 1} & \multicolumn{3}{|c|}{ Fan speed 2} & \multicolumn{2}{|c|}{ Fan speed 3} \\
\hline \multicolumn{4}{|c|}{ External Air flow measurements $\mathrm{m}^{3} / \mathrm{hr}$} & 87 & \multicolumn{2}{|l|}{89} & \multicolumn{3}{|c|}{\begin{tabular}{l|l}
110 & 113
\end{tabular}} & \multicolumn{2}{|c|}{\begin{tabular}{|l|l|}
135 & 138
\end{tabular}} \\
\hline Fan speed s & etting & & & $68 \%$ & $55 \%$ & & $79 \%$ & & & $93 \%$ & $76 \%$ \\
\hline \multicolumn{12}{|c|}{ Electrical consumption measurements with clean filters and F8 intake. } \\
\hline Fans off & & Fan & Speed 1 & & Fan $s$ & peed & & & Fan & peed 3 & \\
\hline $10.5 \mathrm{~W}$ & & 231 & & & $30 \mathrm{~W}$ & & & & 42 & & \\
\hline $0 \mathrm{~m}^{3} / \mathrm{hr}$ & & 721 & $3 / \mathrm{hr}$ & & $99 \mathrm{~m}^{3}$ & & & & 128 & $/ \mathrm{hr}$ & \\
\hline
\end{tabular}

Table 6 Original PHPP Design Calculation; Space Heating Demand and As Measured PHPP Design Calculation

\begin{tabular}{|l|l|}
\hline $\begin{array}{l}\text { ORIGINAL PHPP CERTIFICATION } \\
\text { CALCULATION }\end{array}$ & AS MEASURED PHPP CALCULATION. \\
\hline PHPP London Weather File & Real 2011/12 Weather File \\
\hline T Internal $20^{\circ} \mathrm{C}$ & T Internal $22.4^{\circ} \mathrm{C}$ \\
\hline Internal Heat Gain $2.1 \mathrm{~W} / \mathrm{m} 2$ & Internal Heat Gain $3.7 \mathrm{~W} / \mathrm{m} 2$ \\
\hline MVHR Efficiency $92 \%$ & MVHR Efficiency $82 \%$ \\
\hline Standard Blind Use & Greater Blind Use in Bedroom \\
\hline Space Heating Demand $1307 \mathrm{kWh}, 13.2 \mathrm{kWh} / \mathrm{m}^{2}$ & Space Heating Demand $1185 \mathrm{kWh}, 11.7 \mathrm{kWh} / \mathrm{m}^{2}$ \\
\hline
\end{tabular}



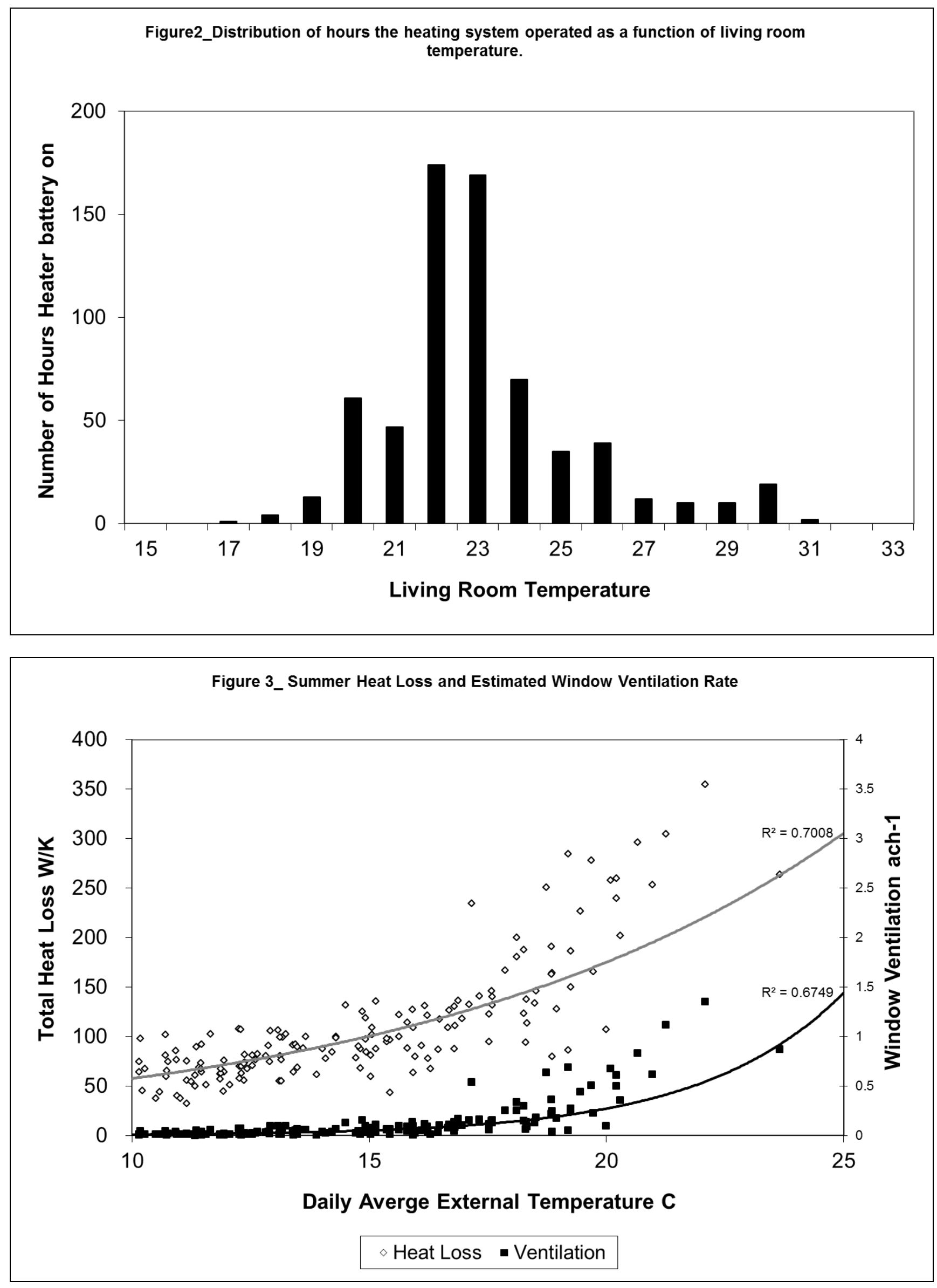

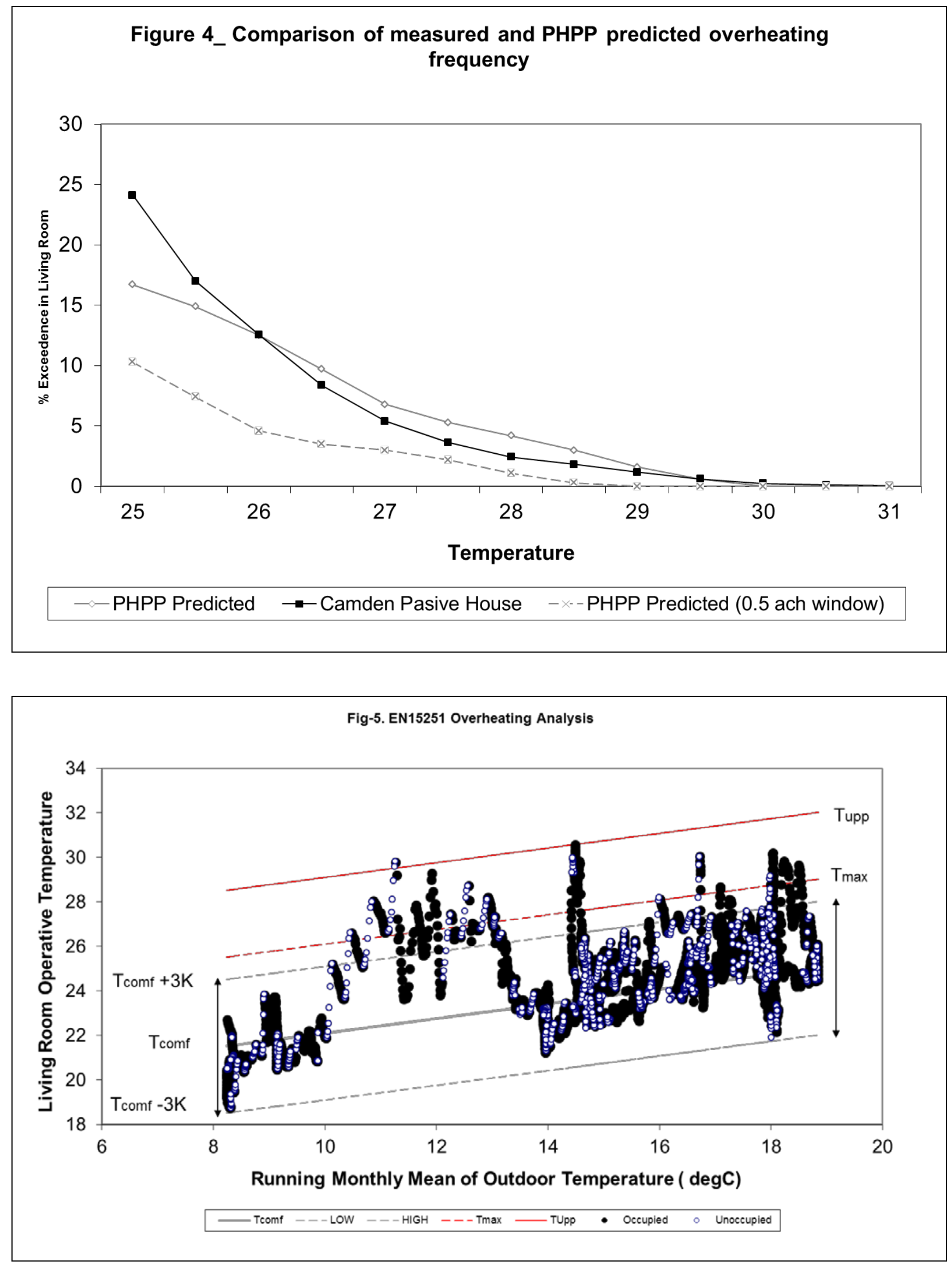

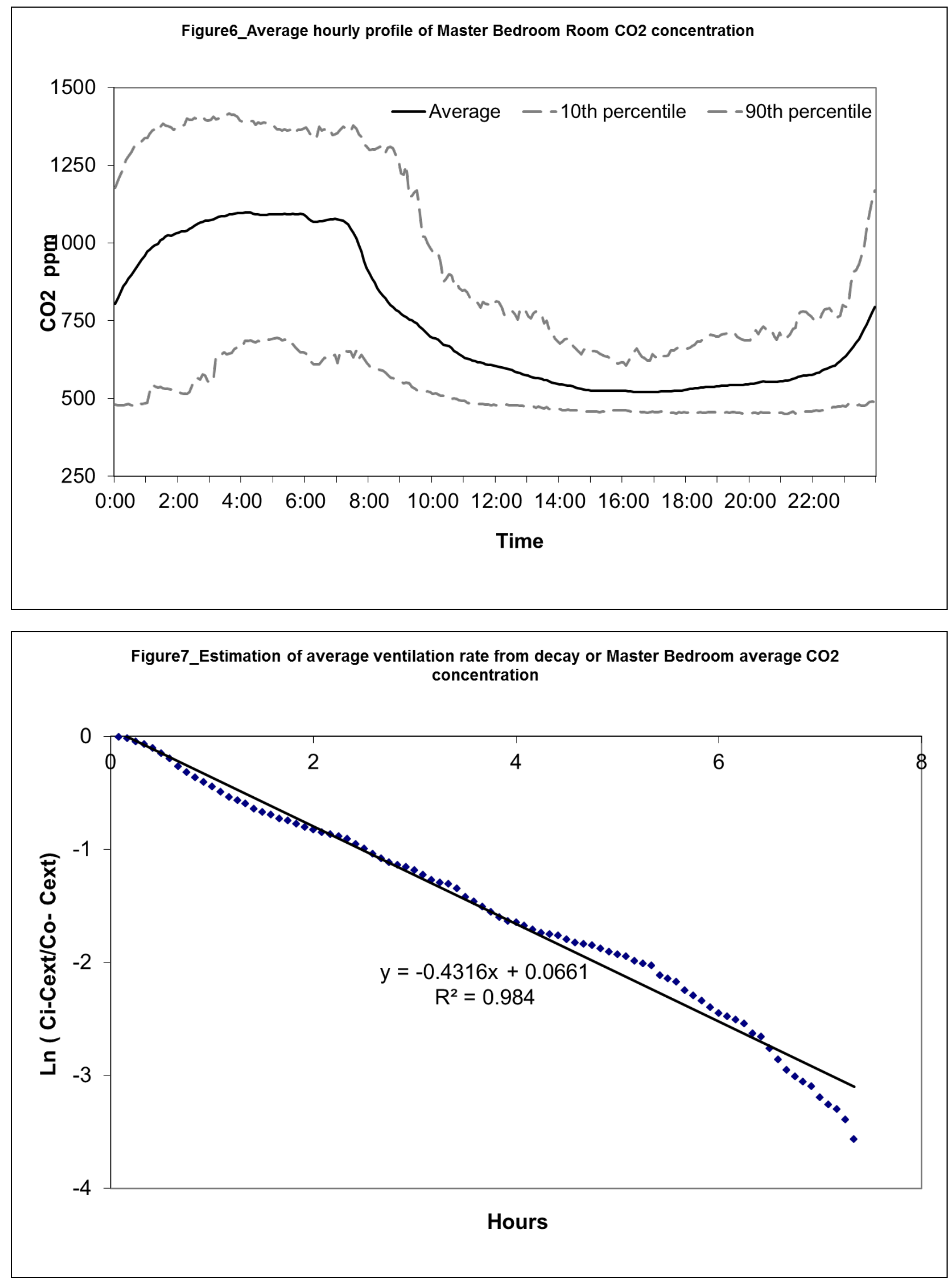
Figure8_Average hourly profile of Gas, Domestic hot water and Space Heating Consumption

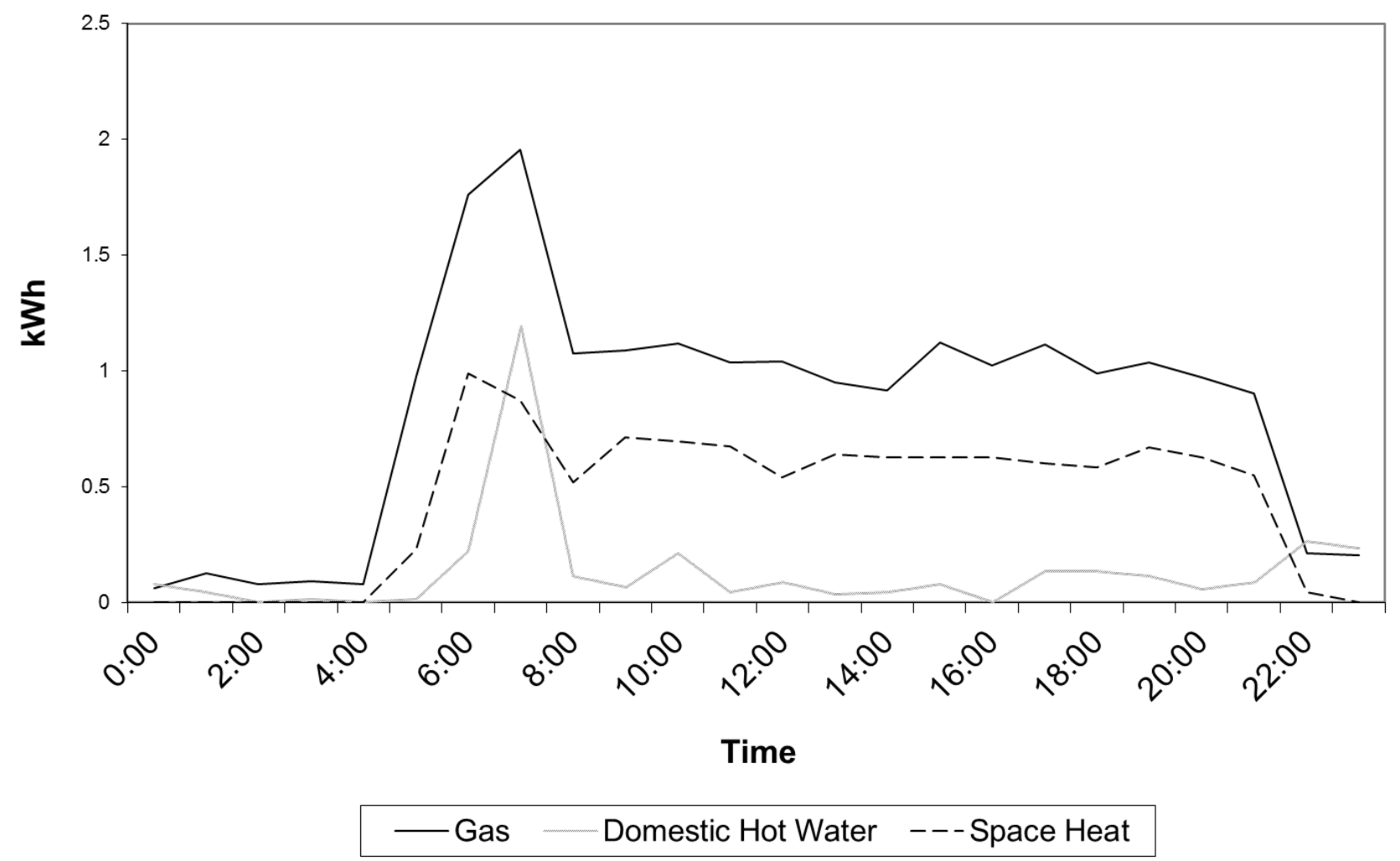

Figure9_Average hourly profile of Electricity Consumption with average UK (EST study) profile

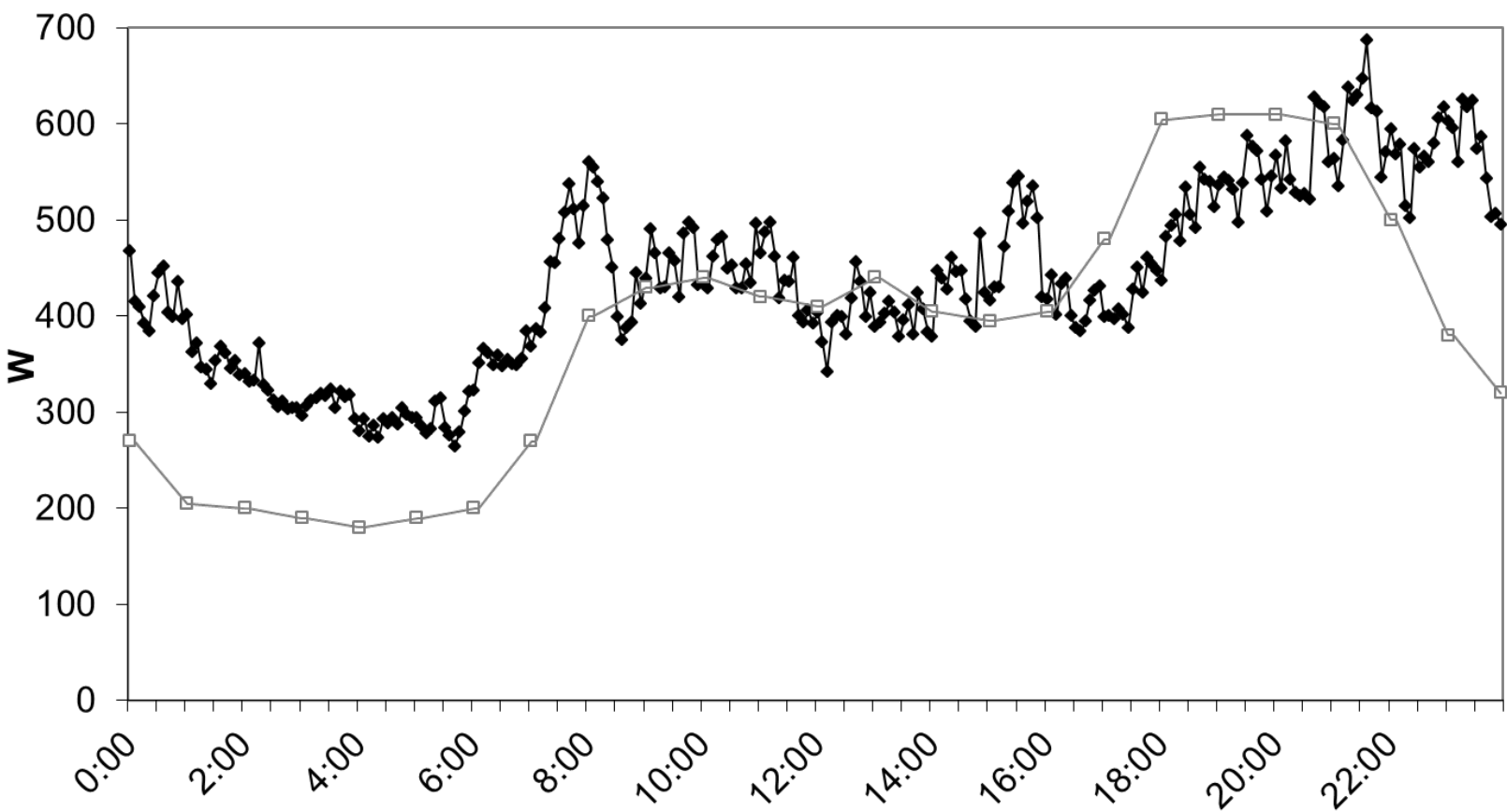

Time

$\rightarrow$ Camden Passive House $\quad-\square-$ Typical UK (EST) 

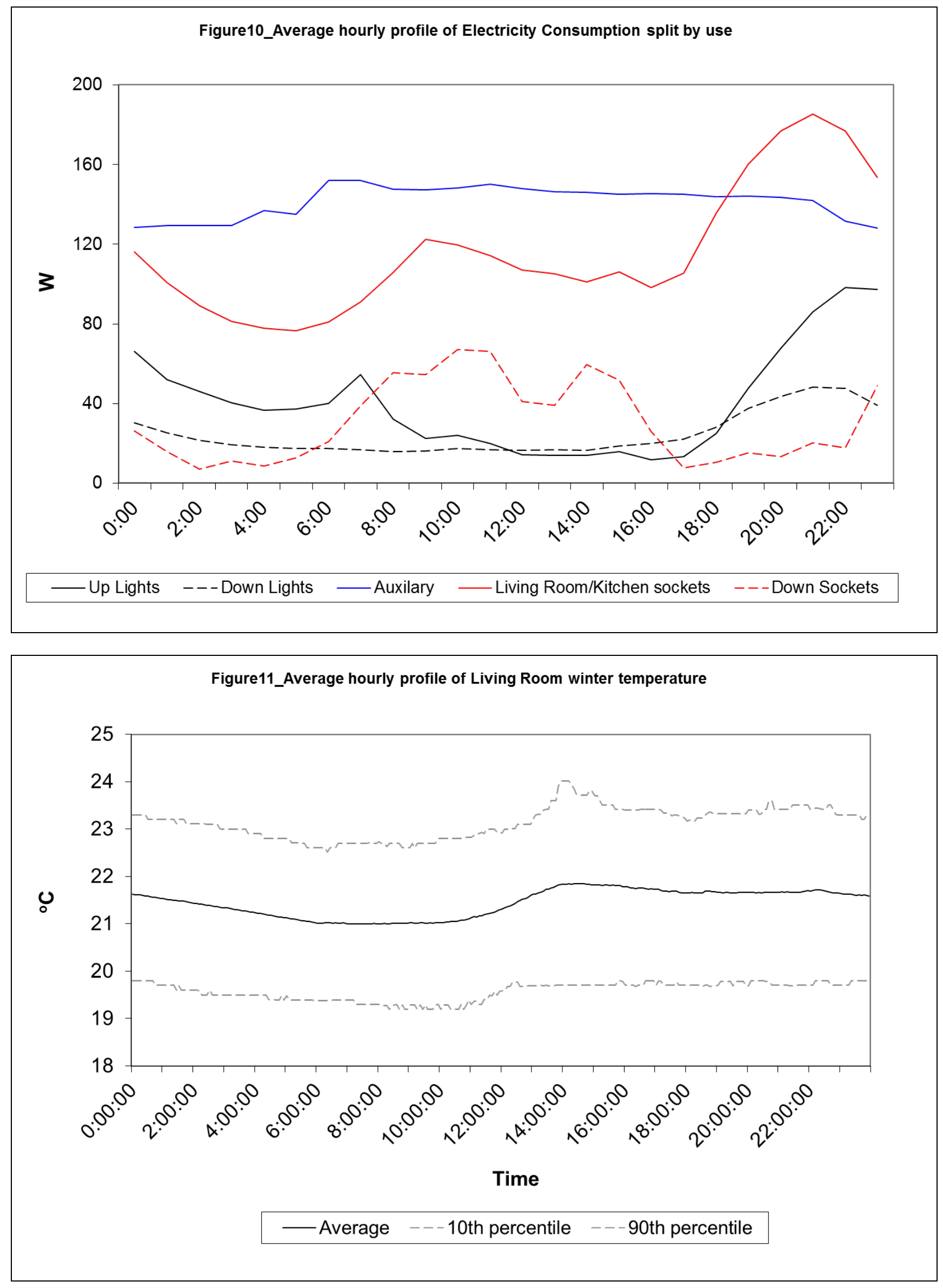
Figure12_Average hourly profile of Master Bedroom winter temperature

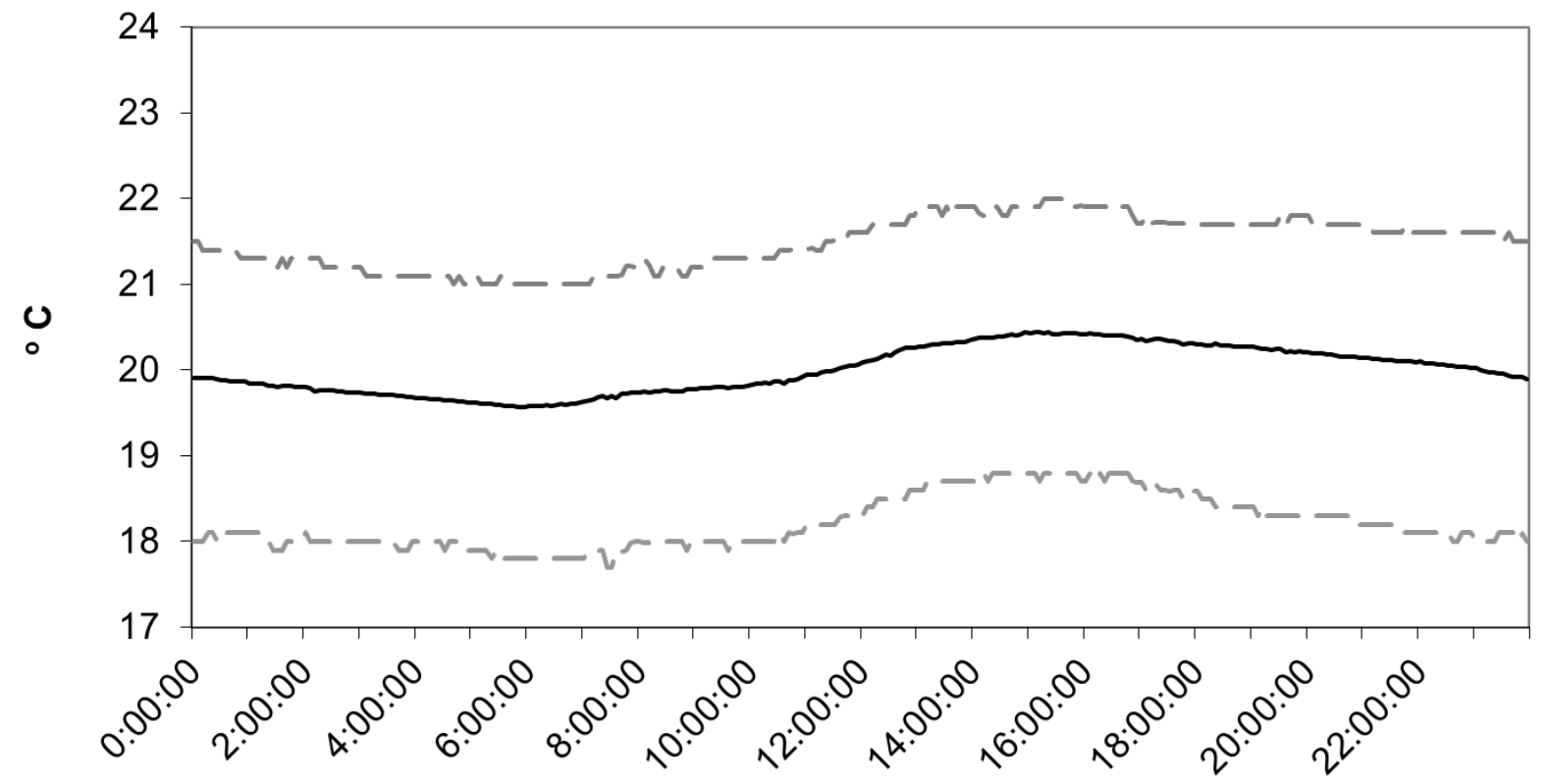

Time

- Average --10 th percentile --90 th percentile

Figure13_Average hourly profile of Living Room summer temperature

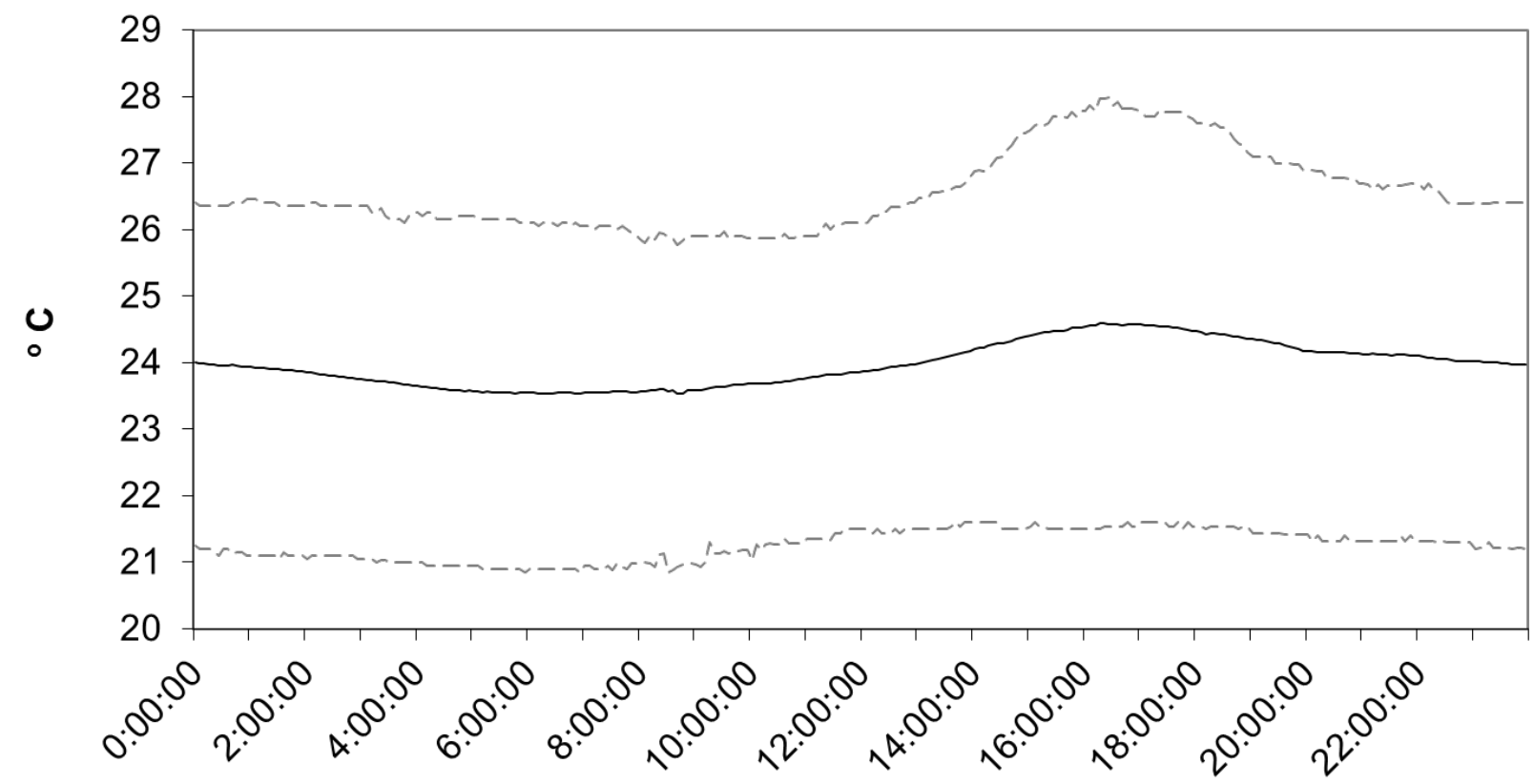

Time

- Average $\quad---10$ th Percentile $\quad---90$ th Percentile




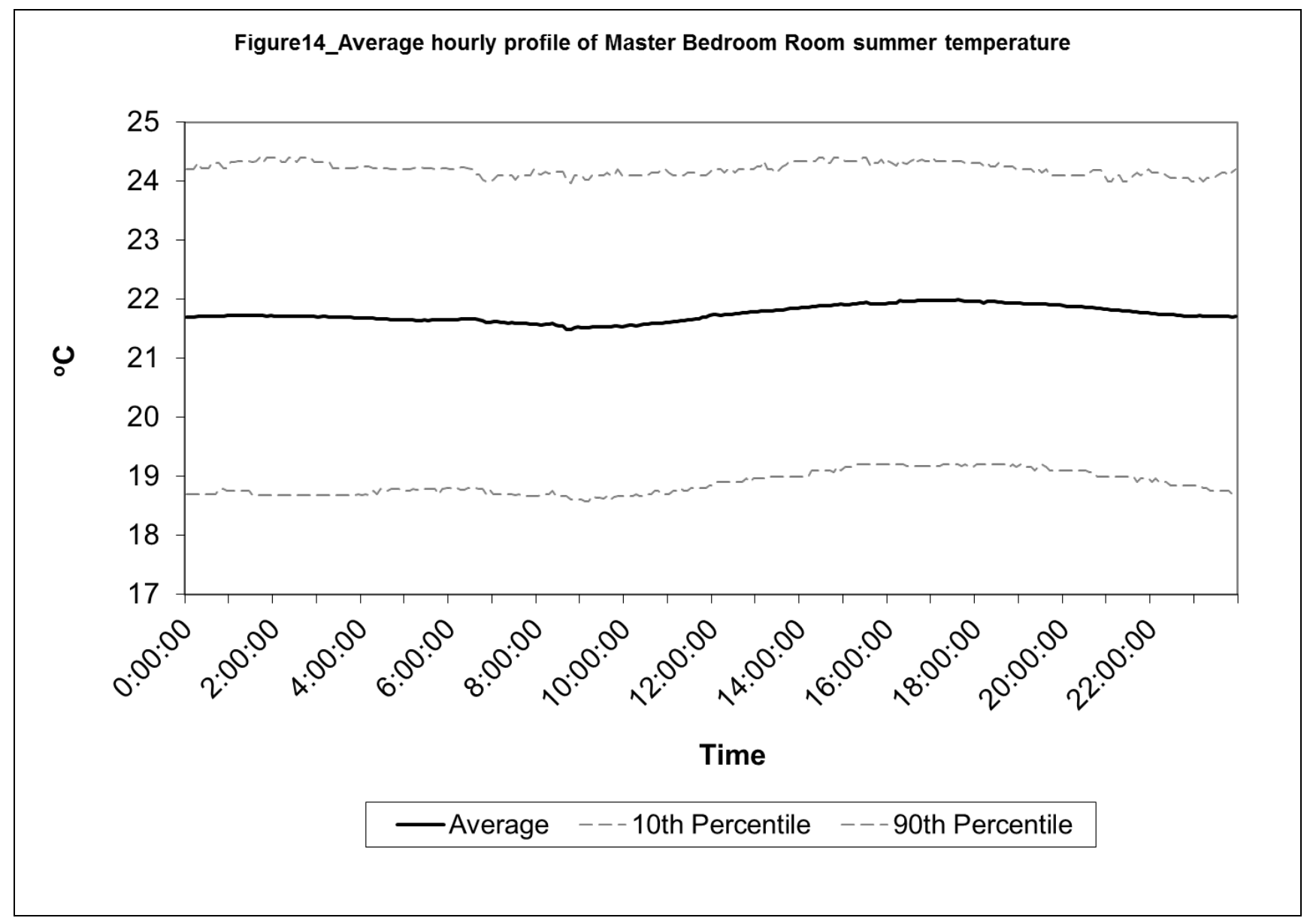

